\title{
The E-Marketing Strategy Process in the Tourism Industry - Case Study Kosovo and Albania
}

\author{
Behrije Ramaj-Desku \\ behrije.ramaj@unhz.eu \\ University 'Haxhi Zeka', Kosovo \\ Faculty of Management in Tourism, Hospitality and Environment
}

Fatos Ukaj

University of Prishtina, Kosovo

Faculty of Economic

\begin{abstract}
The E-marketing strategy is developed as a process of several stages that need to be well analyzed and constantly reviewed. The first stage of this process is situational analysis (internal and external factors). The research was focused on identifying internal and external factors. The Delphi technique was used in combination with the AHP method to answer the research questions. The research was conducted in three stages, according to the Delphi technique. In order to process the data in all three phases of the research Excel, SPSS, and the AHP-ON system were used. 36 experts of tourism industry from Kosovo and Albania took part in this study. Ranked based on the significance, of all factors and sub-factors the following indicated the highest influence: entrepreneurial attitudes and knowledge, management support, customer and supplier relationships, IT cost, competitor identification, competitor analysis, and innovation. Based on the scientific literature and the primary results, the conclusion and recommendations were drawn and a model was proposed by the author based on the contingency theory and the TEO framework.
\end{abstract}

Keywords: E-marketing, strategies, external and internal factors, tourism industry, Kosovo, Albania, Delphi techniques, AHP method, contingency theory.

\section{Introduction}

Nowadays, tourism unites people in ways that were not thought of decades ago, and also has a high influence on the national and regional economy growth. The information technology (IT) applications have a huge impact on the marketing process. The application of IT creates strong competitive advantages in the areas of sales and marketing. Also, through the use of electronic broadcasting channels, social media platforms, and other innovations, suppliers connect to new and different markets [1]. Modern technology is expected to play an even more important role in the tourism industry in the years to come, given the fact that tourist expectations have recently increased in terms of service delivery. For tourism enterprises the application of information technology has influenced the increase of quality in service delivery, 
the possibility of securing market existence, improvement of forms of communication with tourists, selling of tourism products, increasing the possibility of cooperation with other enterprises, increasing of income and cost reduction [2] .

In recent years, within the framework of different marketing strategies, due to the benefits it offers, the attention is on e-marketing strategy. The E-marketing offers new marketing communication opportunities through the leading platform called Internet. Businesses that apply E-marketing achieve higher efficiency, greater return on investment, also through online campaigns, sales and the opportunity to attract potential customers are increased [3].

\subsection{Purpose of the study and research questions}

This paper aimed to answer the research questions related to the factors influencing the E-marketing strategies in the tourism industry, analysis of the existing situation in our country, as well as giving recommendations for improving this situation. The main objective of this paper was to present which factors have the greatest influence on the design and implementation of E-marketing strategy in the tourism industry to hotel companies, airlines, and tour operators.

The research was focused on the most important factors, such as:

- Internal factors

- External factors

In addition, the objective of this research was to address the theoretical part of scientific theories, the marketing environment, and the factors influencing the $\mathbf{E}$ marketing strategy.

\subsubsection{Research Questions:}

Based on the objectives and aims of the research, the following questions were answered:

1. What are the internal factors that influence the E-marketing strategy in the tourism industry in Kosovo and Albania?

2. What are the external factors that influence the E-marketing strategy in the tourism industry in Kosovo and Albania?

3. Are there differences of opinion between the experts of the two countries about the importance of external and internal factors?

4. Which of the external factors is most important in the E-marketing strategy of the tourism industry in Kosovo and Albania?

5. Which of the internal factors is the most important in the E-marketing strategy of the tourism industry in Kosovo and Albania? 


\section{Methodology}

Based on the research models, this research is exploratory and descriptive. The qualitative and quantitative approach assisted to identify the most important aspects of the issue addressed. The descriptive method describes the external and internal factors that influence the process of E-marketing strategy. The research was conducted in three phases, the Delphi method was applied in all three stages, but in the third phase of research AHP (Analytical Hierarchy Process) method was applied in order to rank which of the factors are the most significant in the E-marketing strategy in the tourism industry. The three phases of this research are outlined in Figure 1.

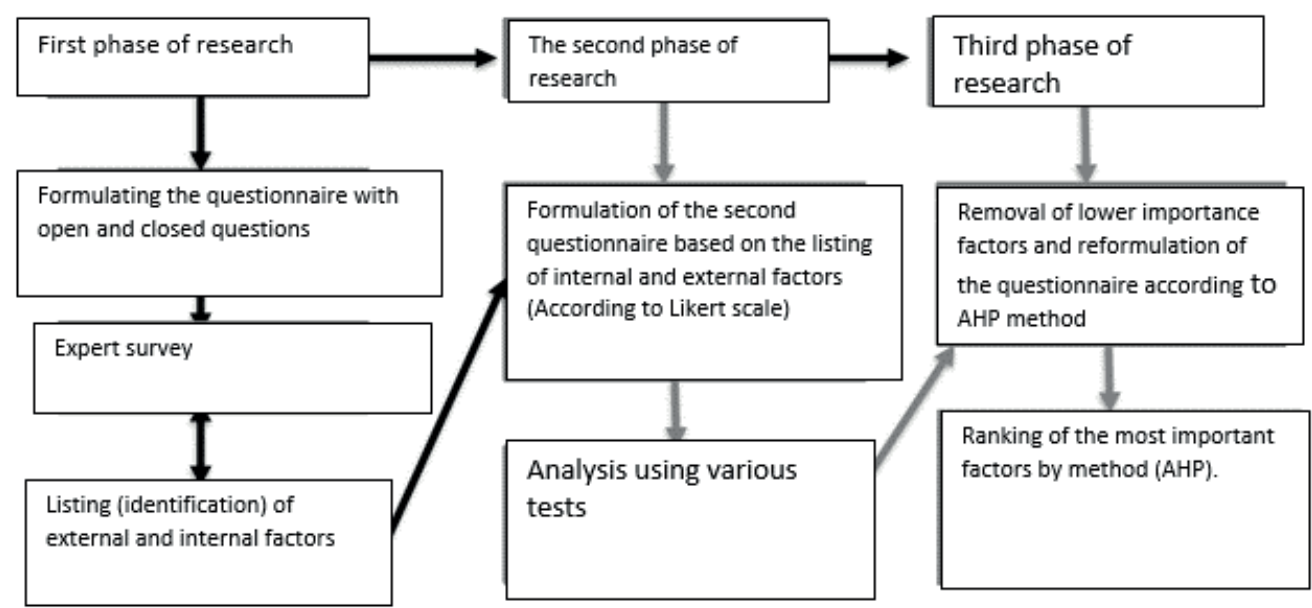

Figure 1. Stages of the research process. Source: Author.

In the the first phase of the research was identified the group of experts with management and decision-making positions to be part of the open-ended questions survey, and to answer the first and second research questions using the Delphi method. In the second phase of the research, the second questionnaire was implemented, from which the answers to the third, fourth and fifth research questions came out. At this stage, various tests were used to analyse the second questionnaire:

- Frideman Test (Ranking)

- Alpha coefficient model (Correlation matrix)

- Independent Samples t Test to compare Kosovo and Albania.

The main focus of the research was to create a common list of influencing factors in three groups of entities: Hotels, airlines, tour operators, and agencies. Initially, the responses of the expert-decision-makers of the field of study to the questions posed by the researcher were analysed. In the second phase of the research, from the subfactors selected from the first questionnaire, a second questionnaire was created where these sub-factors were included. The questionnaire was structured, completed by questions that were predefined (using the Likert scale). The SPSS and Exel were used for this phase. In the third phase of the research, the AHP (Analytical Hierarchy Process) method was applied in order to rank the most important factors in the E- 
marketing strategy in tourism. The method consisted of the main goals of the research then defined the criteria and sub-criteria if any, and at the end of the structure, the alternatives were located. Initially, the two countries Kosovo and Albania were set as alternatives, but [4] suggests that for these research questions the structure of the hierarchical model can be structured without alternatives. He has presented similar examples in his research.

The structure of the hierarchical research model according to the AHP method.

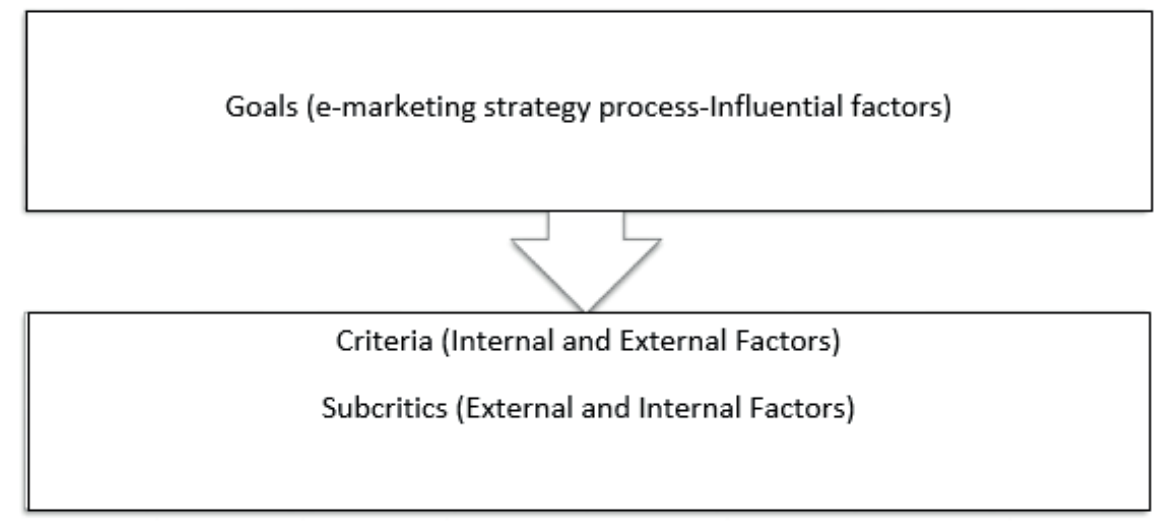

Figure 2. The presentation of research hierarchy (AHP). Source: Adapted according to the author, based on [5].

In Figure 2 the main goals such as the focus on the influencing factors in the Emarketing strategy were presented, the external and internal factors were defined as a criterion, as well as the external and internal sub-factors. The research was based on primary data, original data. As mentioned above, the research was divided into three phases according to the Delphi technique, so in Figure 3 the instruments used to collect the primary data were outlined.

In the first phase of the research, combined techniques for primary data collection were used. For data collection, a self-administered survey form and e-mail survey were selected for the experts' group. In the second and third phases of the survey, the online panel survey was applied. At this stage, the experts' group has responded to the online questionnaire, created at https://my.survio.com/. In the second phase, the questionnaire is structured with closed-ended questions according to the Likert scale. While in the third phase the questionnaire was structured according to the AHP method, also created at https://my.survio.com/.

\section{Scientific theories of strategy building}

The E-marketing is considered as the new high-impact discipline in the field of tourism. The main focus of this paper was to identify the determinant factors in the adoption of E-marketing by different businesses, with the specific focus being on the tourism industry businesses. According to the literature review [6]-[10], the following 
theories are presented that were used to explain the adoption of information technology and the factors influencing E-marketing:

- $\quad$ Theory of Reasoned Action (TRA)

- $\quad$ Theory of Planned Behavior (TPB)

- Innovation Diffusion Theory (IDT)

- Theory of Technological, Organizational and Environmental Framework (TOE)

- Technology Acceptance Model (TAM) and

- $\quad$ The Common Theory of Technology Acceptance and Use (UTAUT)

- Contingency Theory

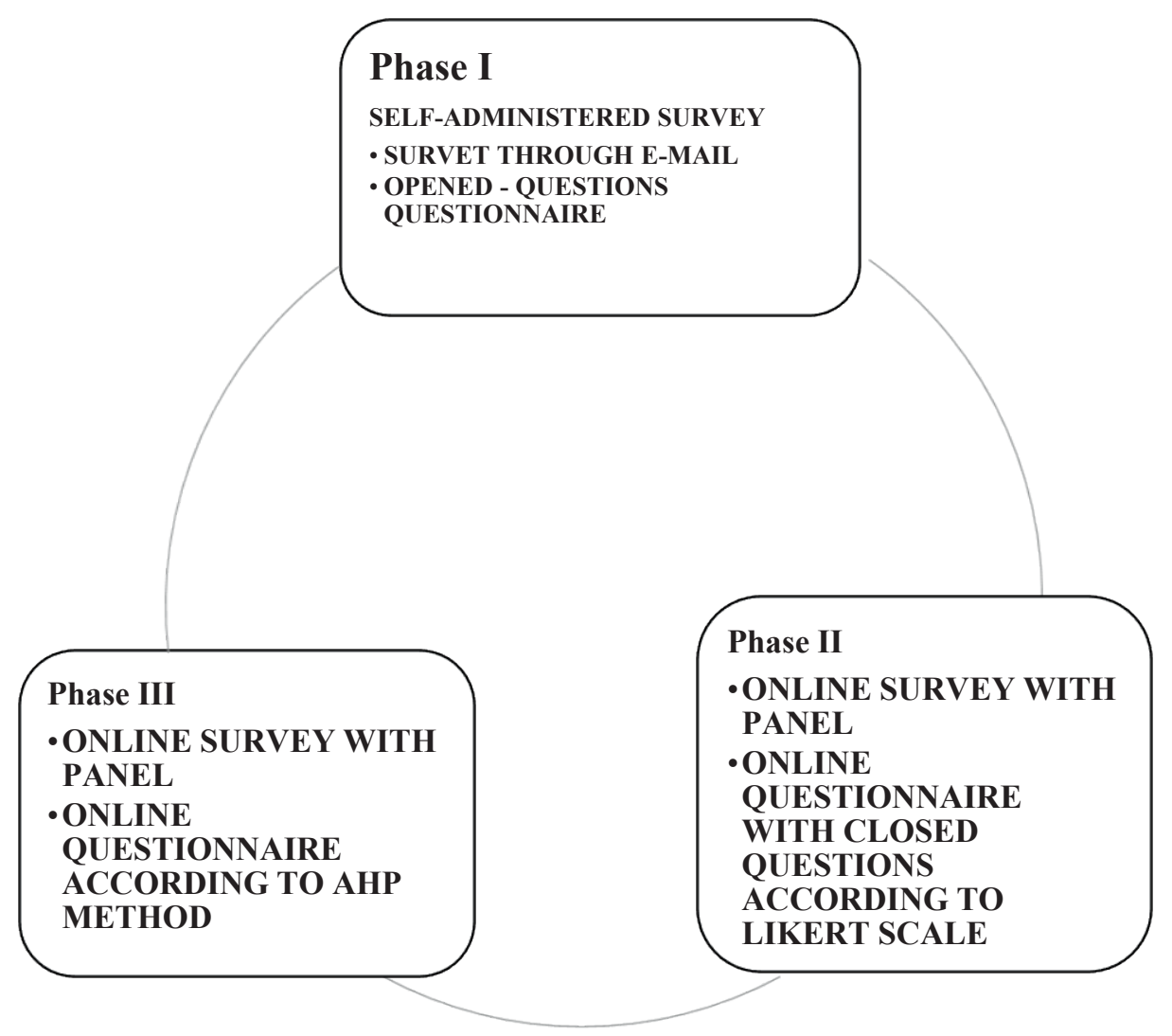

Figure 3. Techniques of primary data collection. Source: Author.

Theory of Reasoned Action (TRA)

The Theory of Reasoned Action (TRA) was proposed by Ajzan and Fishbein, (1980). This theory provides explanations for consumer actions both in the online and offline contexts. Consumer behavior is the result of attitudes that are shaped by perceptions and norms. Attitude toward a behavior is a function of perceived statements related to the behavior and the value to the person, while subjective norms 
can be presented as one's perceptions of normative societal pressure to do or not to perform a particular behavior. Introducing behavioral intention through attitudes and social norm components are considered the best predictors of actual behavior [11][13].

\section{Theory of Planned Behavior (TPB)}

The Theory of Planned Behavior was proposed by the author Ajzen. According to this theory, conducting a behavior is conceived as a common function of goals and perceived behavioral control. The theory of planned behavior deals with antecedents of attitudes, subjective norms, and perceived behavioral control, antecedents which in the final analysis determine goals and actions. The Theory of Planned behavior provides a useful conceptual framework for dealing with the complexities of human social behavior [14]. In the following figure is illustrated the Theory of Planned Behavior (TPB):

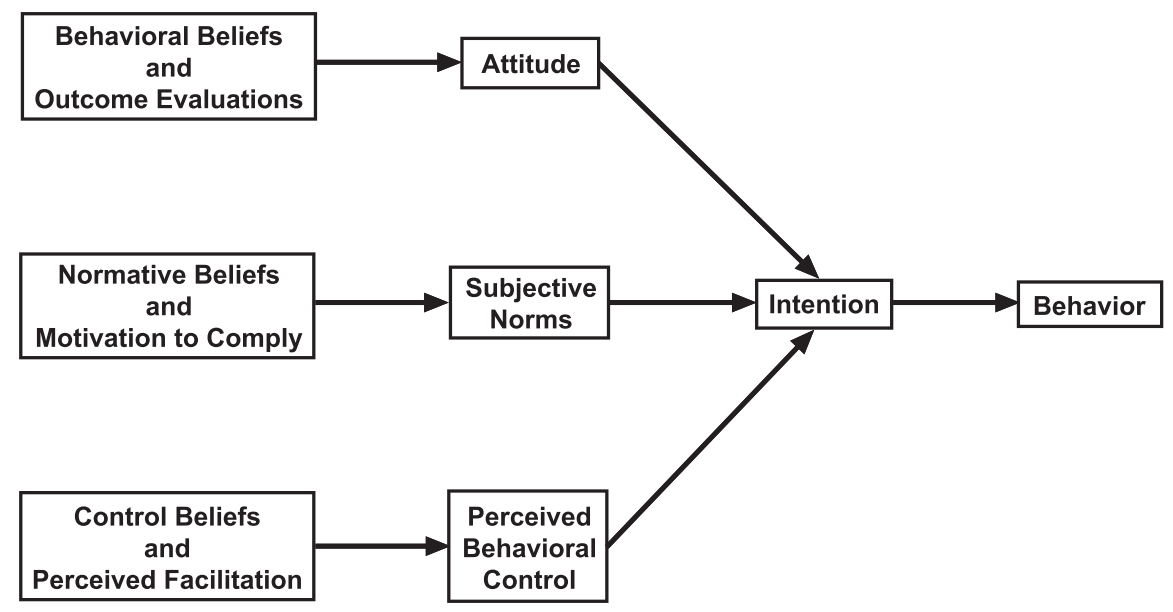

Figure 4. Planned Behavior Theory. Source: Mathieson, (1991)

According to Azjen, (1985) cited in [16], an attitude towards a behavior is a positive or negative assessment of the conduct of that behavior. The attitudes are informed by beliefs, the norms are informed by normative beliefs and motivation to be fulfilled, while the perception of behavioral control is informed by beliefs about mastering the possibilities of individuals and resources needed to engage in a behavior (Azjen, 1991 cited in [16]).

Innovation Diffusion Theory (IDT)

According to [17] "Diffusion" is the process by which an innovation is communicated through certain channels in time between members of a social system. Communication is a process in which participants create and share information in order to reach a mutual understanding."

Technological, Organizational and Environmental Context (TOE)

The TOE identifies the three most important aspects that influence the process of an enterprise to adopte and implement a technology. This framework was developed in 1990 by Tornatzky and Fleischer. According to them, the most important aspects 
are: technological context, organizational context and environmental context [18]. In Figure 5 is shown the technological, organizational, and environmental structure:

- The technological context encompasses all technologies that are in use by the firm, and in this context is also included the technology available in the market. So, it is available to the firm but does not currently use it due to different reasons [18], [20].

- The organizational context refers to firm characteristics and resources, including organizational structure, the connection of structures between employees, firm size, and quantity[18], [20].

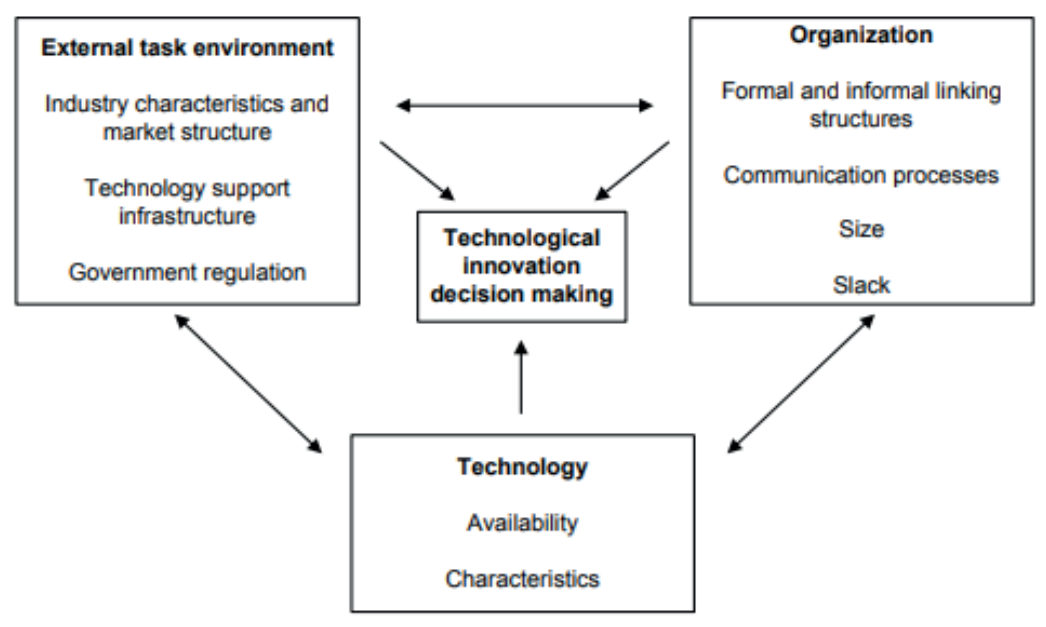

Figure 5. TOE Structure. Source: (Tornatzky dhe Fleischer, 1990) [19].

- The environmental context includes the industry structure, presence or absence of technology service providers, and the regulatory environment. The environmental context, which refers to the arena in which a firm conducts its business; it can be linked to surrounding elements such as industry, competitors, and the presence of technology service providers [18], [20].

Technology Acceptance Model (TAM) and Common Technology Acceptance and Use Theory (UTAUT)

Concerning the literature review, many researchers who have aimed to elucidate how technology is accepted by consumers, organizations, various businesses belonging to the tourism industry and the factors that have influenced the technology adoption, the E- marketing adoption, have used the Technology Acceptance Model (TAM) and the Common Technology Acceptance and Use Theory (UTAUT) [6]-[8], [11], [21]-[34]. 
Technology Acceptance Model (TAM) and Common Technology Acceptance and Use Theory (UTAUT).

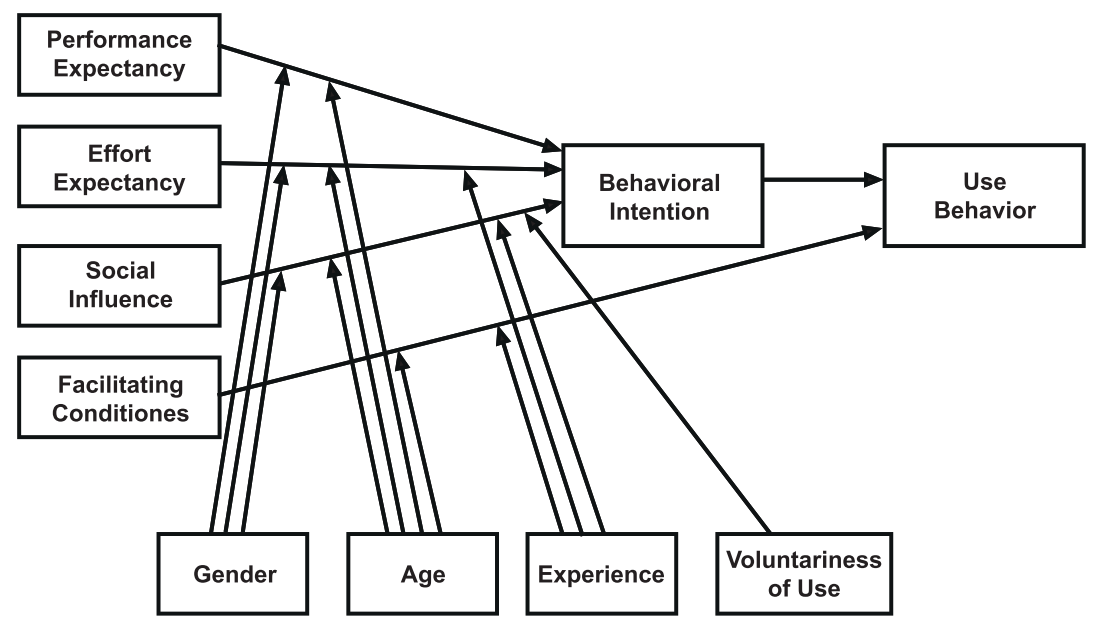

Figure 6. UTAUT Model. Source: [35], [36] .

The UTAUT model is used to explain the goals of the use of information systems in the context of the acceptance and use of technology by the customer. These goals are identified through the four main constructs and mediating factors. The four main constructs are: (performance expectancy, effort expectancy, social influence and facilitating conditions), while the mediating factors are: (gender, age, experience, and voluntariness of use) [6], [7], [33], [37].

\section{Contingency Theory}

The contingency theory is conceptually rooted in the fact that strategies to achieve goals and be effective depend heavily on the collision between strategy, organization, and the environment.

This theory has been used in the $70 \mathrm{~s}$ and $80 \mathrm{~s}$, but it still offers important opportunities for SI researchers [38]. The primary focus of contingency theory, therefore, has traditionally been on the relationship between organizational factors, environmental characteristics, and the strategic response of the organization [39] The contingency theory is constructed on the basis of several steps involving three types of variables: contingency variables, performance variables, and response variables [40]. According to Lages \& Jap, (2002) the coordination between strategy and enterprise context (eg organizational characteristics and external environment) has a positive impact on performance. The contingent approach emphasizes that a good strategy does not exist for all cases, but should be adapted based on the contingent variables [41]. Figure 7 shows the structure of the contingency theory.

In figure 7 is presented the conceptual scheme of contingency theory, where it is worth noting that external and internal contingent factors result in the decisionmaking process for strategy determination. This scheme was used to propose a model, with determinants, as explained in detail in the recommendation section. 


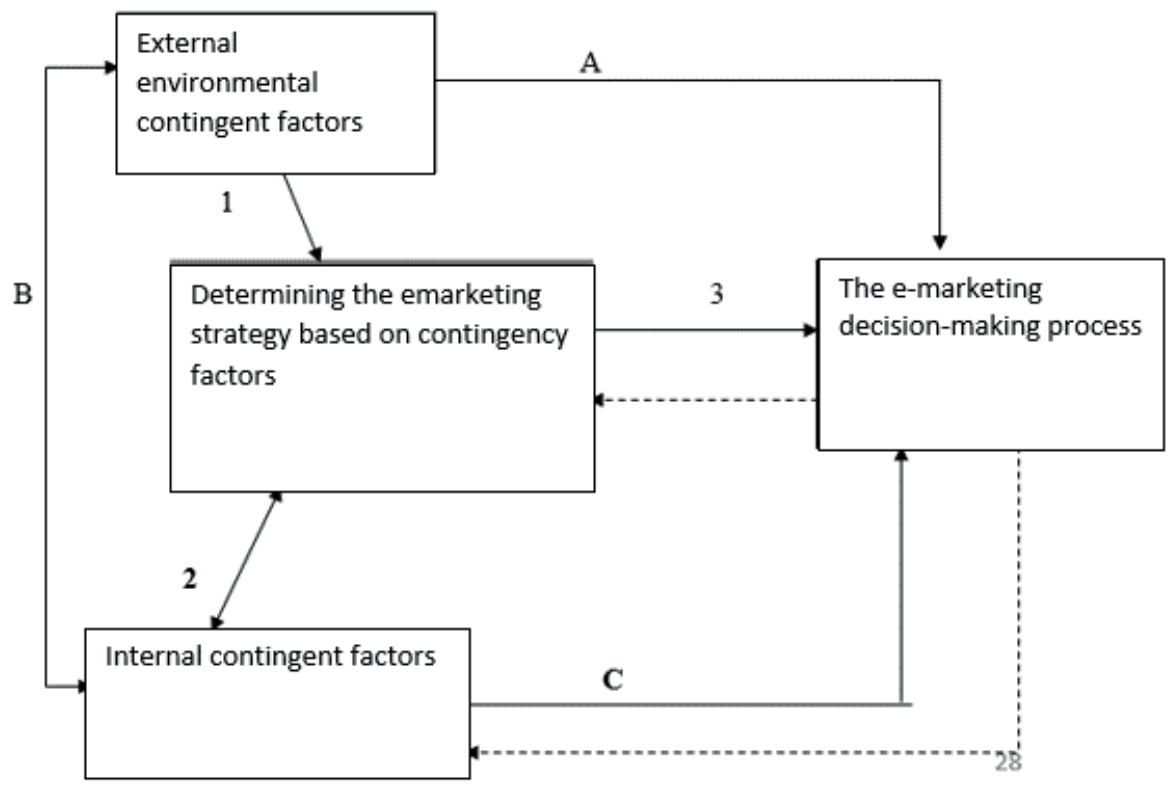

Figure 7. Conceptual scheme on contingency theory. Source: Adapted by author [38].

\subsection{Influential factors on E-marketing, internet marketing and E-tourism}

The influence of external and internal factors on the application of information technology has been researched by many scholars. In Table 1 is included a summary of some of the authors who have analyzed the influential factors on IT, E-marketing, internet marketing, and E-tourism. In particular, the factors that influence a company's attitude towards E-marketing, when defining E-marketing strategy as part of the marketing strategy within the overall strategy.

\begin{tabular}{|l|}
\hline FACTORS / VARIABLES / CHARACTERISTICS: \\
\hline Factors influencing the penetration of E-tourism in organisations: \\
- The cost of purchasing the hardware, software and communication \\
package, the cost of training users, designing and building an online \\
presence, the cost of keeping the site on a reliable server, ongoing \\
maintenance and regular updating, developing treatment procedures of \\
online presence, commissions for online purchases from intermediaries, \\
advertising fees for representation in search engines and other countries, \\
and interconnectedness with travel intermediaries [42]
\end{tabular}


Factors influencing E-marketing strategy:

- Influential elements of the environment (IT and the cost of telecommunications infrastructure, IT general knowledge and culture in society, market (skills, potential, turbulence, orientation), competitiveness and competitors' strategies, availability of resources and environmental opportunities, the human resource market (IT \& E-Marketing Specialists), IT and e-commerce government policies, laws, regulations, systems standards of IT and technology, innovation, skills, changes in business and marketing models ( Time \& Process);

- Company elements (products, service quality and varieties, Web marketing mix strategy, Resource availability (Finance, Technology, etc.), brand and its strategy, strategic relationships and alliances, customer segmentation and targeting, restructuring and reorganization processes, IT infrastructure of firm, station and orientation, strong competitive advantages in emarketing, support for innovation and knowledge management, increased internet traffic and sensitivity,)

- Influential elements in customer satisfaction (web and brand reliability, security, privacy and trust, website (attraction, design, availability and quality), transmission speed and conversion rate, tourist needs, experience and market expectations, support and structure of purchase, products and quality of service, variety and innovation, flexibility and individualization of products and services, price advantage and cost for customers, adaptation (Service and level of CRM coverage), added value perceived by customers [44].

The main organizational variables and motives (reasons) of e-business:

- Firm characteristics (size, age, scope of industry and market),

- Business strategy (strategic orientation and new product strategy),

- Owner characteristics (age, education and leadership style) [45]

The main environmental factors on Internet success:

- Resourceful and essential information should be presented to customers, the website should be well designed, and the design of the website should pay attention to e-trust/reliability because the content of the website can attract the customer and convince them to purchase [46]

Individual characteristics that affect ICT approval:

- Gender, age, level of education, computer and Internet skills [9].

Dimensions of e-marketing skills:

- IT resources (e-commerce websites that offer sales, intranet, extranet, customer relationship management system, etc.).

- Human resources;

- Business resources [47]

Factors influencing the application of Online Marketing in SMEs:

- Internal factors (owner, characteristics of the organization/enterprise);

- External factors (technological, governmental factors)

- Demand factors [48]. 
The main stakeholders that have a role in the introduction of IT from SMEs to hotels; Driving factors (education \& training, European Union, government \& public agencies, strategic partners, strategic shift)

- Attractive factors (customer demand, interconnection, intranet, extranet, internet, travel trade, accounting systems [49].

Internal and external factors that affect small businesses in the use of electronic marketing:

- Internal factors (owners' skills, resources, culture and size);

- External factors (competition and market trends) (El-Gohary, 2012 cited in [50]

Factors affecting the adaptation of technology by small businesses:

- The support of senior management, product features organizational readiness (size, cost, access, technical and financial resources), information intensity, industry pressure (competition), national infrastructure, safety, readiness and pressure, support of technology vendors, the international orientation of the enterprise and the skills of the owner (El-Gohary, 2012).

Factors affecting the current and future level of a firm in the approval of ebusiness:

- Being able to understand the potential benefits of e-business, being able to respond to the practices, customers and competitors, trying to develop staff skills and knowledge of Internet-based technologies [51].

Key factors for effective internet marketing:

- Factors related to marketing strategy, websites-related factors, factors related to the global dimension, internal factors, external factors [22].

The main factors influencing social media strategy

- Leadership, social media recognition as a powerful marketing tool and a champion in the organization to promote this marketing medium[52] .

The main factors influencing the rapid recognition and approval of social media

- Consumer perception that WEB 2.0 is a source of empowerment for users as participants in the market process, the fact that for a growing number of Internet users WEB 2.O has become an indispensable element in their social environment[53].

Characteristics that affect the use of internet-based marketing:

- Technological characteristics (security and privacy, convenience and use);

- Organizational characteristics (attitude and knowledge of entrepreneurs, suitability of use and technical availability of the firm);

- Environmental characteristics (consumer pressure, competitor pressure and government support [23], [54].

Table 1. Summary of influential factors. Source: Adapted by the author

At the general level of the enterprise, it is important to clearly define the strategy in a comprehensive aspect. The marketing department should have, operate, implement, and monitor clear E-marketing policies. To what extent a company applies E-marketing, it affects the cost and resources an organization has and whether it is 
part of the E-marketing culture. Similarly, infrastructure, competitive pressures, market trends, and government policies are considered external factors with a high impact on E-marketing adaptation. It is important to analyze the characteristics of the owner (manager) especially variables such as level of education, age, and general knowledge in the technological aspect of the manager. Whereas, the characteristics of the property are emphasized in what size or type the enterprise is, the ways of management, the organizational structure, and it is important how much the application of ICT in the hospitality industry finds support from the management. In order to support ICT, one must know the benefits and barriers that may be encountered with the application of ICT. Various authors have pointed out that the elements of the environment, company, customer satisfaction, IT characteristics, marketing functioning within the company, factors related to marketing strategy, and clear strategy definition are the factors that should be considered as priorities when the Emarketing strategy is defined.

\section{Analysis and presentation of results}

In the introductory part, the research questions were specified, but in this part they are presented and detailed under the questions, in order to achieve authentic results. In the following, the results of the first, second and third phase will be presented.

\subsection{First phase results}

In this section, the answers to the opened research questions are shown, which are also divided into other sub-questions:

1. What are the internal factors that influence the E-marketing strategy in the tourism industry in Kosovo and Albania?

2. What are the specific environmental factors that influence the Emarketing strategy in the tourism industry in Kosovo and Albania?

3. What are the general environmental factors that influence the Emarketing strategy in the tourism industry in Kosovo and Albania?

The general environmental factors were addressed more specifically through the four other questions:

1. What are the technological factors that influence the E-marketing strategy in the tourism industry in Kosovo and Albania?

2. What are the economic factors that influence the E-marketing strategy in the tourism industry in Kosovo and Albania?

3. What are the political and legal factors that influence the E-marketing strategy in the tourism industry in Kosovo and Albania?

4. What are the cultural and social factors that influence the E-marketing strategy in the tourism industry in Kosovo and Albania? 


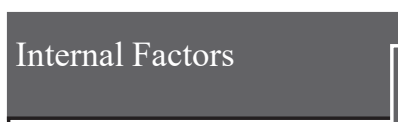

Convenience of use and technical availability; Cooperation between firms, firm characteristics; Owner / manager characteristics; Management support; Operation of marketing and E-marketing activities; Attitudes and knowledge of entrepreneurs and

Human resources skills in Emarketing

\section{Specific environmental}

\section{factors}

Competitor identification and competitor analysis;

Relationships with customers and suppliers and

Partners/associates
General environmental

\section{factors}

\section{Technological factors:}

Innovations;

IT cost;

IT systems standards;

Human resources market and

Application Convenience

Economic factors:

The cost of E-marketing adaptation; The cost of purchasing the software package;

The cost of maintaining a website (reliable server);

Advertising fees for representation in search engines;

The cost of installation or service and

The cost of hiring specialists

Political and legal factors:

National government policies on IT and e-commerce;

Laws and regulations;

Government influence and support;

Security and privacy;

Adaptation of international policies;

Lack of cyber laws and

Government investments

Cultural and social factors:

The general culture of the organisation;

Cultural orientations towards emarketing by the organisation's clients;

General knowledge of society in information technology;

Role and status in society

University quality program level.

Figure 8. List (identifying) of internal and external factors from the first phase of research. Source: Author 


\subsection{The second phase of research}

In the first phase, the factors that emerged from the opened questions from the first questionnaire are summarized. These above-mentioned factors served to create the second questionnaire with closed questions according to the Likert scale.

In this part were given answers to the following questions that were outlined in the introduction section:

1. Are there any differences in the opinions of experts from both countries about the importance of external and internal factors?

2. Which of the internal factors is the most important in the E-marketing strategy in the tourism industry in Kosovo and Albania?

3. Which of the external factors is the most important in the E-marketing strategy in the tourism industry in Kosovo and Albania?

Also, at this stage, the external factors in specific and general environmental factors were analyzed as addressed in the first phase of the research.

The data collected from the second phase were subjected to statistical tests such as: Alpha Coefficient, Independent Samples t-Test, and Frideman Test.

\begin{tabular}{|l|c|c|c|}
\hline Factors & $\begin{array}{l}\text { Cronbach's } \\
\text { Alpha }\end{array}$ & $\begin{array}{l}\text { Cronbach's Alpha } \\
\text { Based on } \\
\text { Standardized Items }\end{array}$ & $\begin{array}{l}\text { No. of } \\
\text { Items }\end{array}$ \\
\hline Internal factors & .745 & .781 & 8 \\
\hline Special environmental factors & .649 &. & 3 \\
\hline Technological factors & .805 & .804 & 5 \\
\hline Economic factors & .839 & .842 & 6 \\
\hline Political and legal factors & .777 & .765 & 7 \\
\hline Cultural and social factors & .764 & .762 & 5 \\
\hline
\end{tabular}

Table 2. Alpha Coefficient Results (Cronbach Alpha Coefficient). Source: Author.

The alpha coefficient of 0.745 indicates that the mean used for the internal factors significance is very reliable.The alpha coefficient of 0.649 indicates that the mean used for the specific factors significance is very reliable. The alpha coefficient of 0.850 indicates that the mean used for the significance of technological factors is highly reliable. The alpha coefficient of 0.839 indicates that the mean used for the significance of economic factors is highly reliable.The alpha coefficient of 0.777 indicates that the mean used for the significance of political and legal factors is reliable. The alpha coefficient of 0.764 indicates that the mean used for the significance of cultural and social factors is reliable.

\section{Independent Samples t-Test}

Through this test were given answers to the question: Are there any differences in the opinions of experts of the two countries about the importance of internal factors? 
The research was focused on the group of experts in Kosovo and Albania. Based on this, the hypotheses were confirmed by this test, such as:

Ho: There are no differences between internal influencing factors on E-marketing strategy

Ha: There are differences between internal influencing factors on E-marketing strategy

\begin{tabular}{|c|c|c|c|c|c|c|c|c|c|c|}
\hline \multicolumn{11}{|c|}{ Independent Samples Test } \\
\hline & & \multicolumn{9}{|c|}{\begin{tabular}{|l|l} 
Levene's Test for $t$-test for Equality of Means \\
Equality of \\
Variances
\end{tabular}} \\
\hline & & \multirow[t]{2}{*}{$F$} & \multirow[t]{2}{*}{ Sig. } & \multirow[t]{2}{*}{$\mathrm{t}$} & \multirow[t]{2}{*}{$\mathrm{Df}$} & \multirow[t]{2}{*}{$\begin{array}{l}\text { Sig. (2- } \\
\text { tailed) }\end{array}$} & \multirow[t]{2}{*}{$\begin{array}{c}\text { Mean } \\
\text { Difference }\end{array}$} & \multirow{2}{*}{$\begin{array}{c}\text { Std. } \\
\text { Error } \\
\text { Differen } \\
\text { ce }\end{array}$} & \multicolumn{2}{|c|}{$\begin{array}{l}95 \% \text { Confidence } \\
\text { Interval of the } \\
\text { Difference }\end{array}$} \\
\hline & & & & & & & & & Lower & Upper \\
\hline \multirow{2}{*}{$\begin{array}{l}\text { Firm } \\
\text { characteristi } \\
\text { cs }\end{array}$} & $\begin{array}{l}\text { Equal variances } \\
\text { assumed }\end{array}$ & 10.113 & .003 & -.439 & 34 & .664 & -.222 & .507 & -1.252 & .807 \\
\hline & $\begin{array}{l}\text { Equal variances } \\
\text { not assumed }\end{array}$ & & & -.439 & 29.672 & .664 & -.222 &. .507 & -1.257 & .813 \\
\hline \multirow{2}{*}{$\begin{array}{l}\text { Owner / } \\
\text { manager } \\
\text { characteristi } \\
\text { cs }\end{array}$} & $\begin{array}{l}\text { Equal variances } \\
\text { assumed }\end{array}$ & .036 & .851 & 2.007 & 34 & .053 & .556 & L.277 & -.007 & 1.118 \\
\hline & $\begin{array}{l}\text { Equal variances } \\
\text { not assumed }\end{array}$ & & & 2.007 & 33.634 & .053 & .556 & L.277 & -.007 & 1.118 \\
\hline \multirow[t]{2}{*}{$\begin{array}{l}\text { Management } \\
\text { support }\end{array}$} & $\begin{array}{l}\text { Equal variances } \\
\text { assumed }\end{array}$ & .000 & 1.00 & -.213 & 34 & .832 & -.056 & .260 & -.584 & .473 \\
\hline & $\begin{array}{l}\text { Equal variances } \\
\text { not assumed }\end{array}$ & & & -.213 & 33.998 & .832 & -.056 & .260 & -.584 & .473 \\
\hline \multirow{2}{*}{$\begin{array}{l}\text { Operation of } \\
\text { marketing } \\
\text { and e- } \\
\text { marketing } \\
\text { activities }\end{array}$} & $\begin{array}{l}\text { Equal variances } \\
\text { assumed }\end{array}$ & .040 & .843 & -.867 & 34 & .392 & -.222 & .256 & -.743 & .299 \\
\hline & $\begin{array}{l}\text { Equal variances } \\
\text { not assumed }\end{array}$ & & & -.867 & 33.934 & .832 & -.222 & .256 & -.743 & .299 \\
\hline \multirow{2}{*}{$\begin{array}{l}\text { Entrepreneur } \\
\text { s' attitudes } \\
\text { and } \\
\text { knowledge }\end{array}$} & $\begin{array}{l}\text { Equal variances } \\
\text { assumed }\end{array}$ & .399 & .532 & .000 & 34 & 1.000 & .000 & .246 & -.500 & .500 \\
\hline & $\begin{array}{l}\text { Equal variances } \\
\text { not assumed }\end{array}$ & & & .000 & 33.610 & 1.000 & .000 & .246 & -.501 & .501 \\
\hline \multirow{2}{*}{$\begin{array}{l}\text { Human } \\
\text { resources } \\
\text { skills in e- } \\
\text { marketing }\end{array}$} & $\begin{array}{l}\text { Equal variances } \\
\text { assumed }\end{array}$ & .102 & .751 & -.766 & 34 & .449 & -.222 & .290 & -.812 & .368 \\
\hline & $\begin{array}{l}\text { Equal variances } \\
\text { not assumed }\end{array}$ & & & -.766 & 33.839 & .449 & -.222 & .290 & -.812 & .368 \\
\hline \multirow{2}{*}{$\begin{array}{l}\text { Cooperation } \\
\text { between } \\
\text { departments }\end{array}$} & $\begin{array}{l}\text { Equal variances } \\
\text { assumed }\end{array}$ & .531 & .471 & .000 & 34 & 1.000 & .000 & .291 & -.592 & .592 \\
\hline & $\begin{array}{l}\text { Equal variances } \\
\text { not assumed }\end{array}$ & & & .000 & 33.800 & 1.000 & .000 & .291 & -.593 & .593 \\
\hline \multirow{2}{*}{$\begin{array}{l}\text { Convenience } \\
\text { of use and } \\
\text { technical } \\
\text { availability }\end{array}$} & $\begin{array}{l}\text { Equal variances } \\
\text { assumed }\end{array}$ & 2.109 & .156 & -.200 & 34 & .843 & -.056 & .278 & -.620 & .509 \\
\hline & $\begin{array}{l}\text { Equal variances } \\
\text { not assumed }\end{array}$ & & & -.200 & 31.528 & .843 & -.056 & .278 & -.622 & .511 \\
\hline
\end{tabular}

Table 3. Independent sample t-test for internal factors. Source: Author.

Based on the results of the t-test for Equality of Means, we were based on Sig. (2tailed), to prove the hypothesis raised above. The points are (.664, .832, .392, 1,000, $.449,1.00 .843$ ), have a value greater than 0.05 except for one question that has a 
value of 0.053 . With a level of $95 \%$ reliability, it can be said that there are no significant differences in the significance of internal factors in Kosovo and Albania.

$\mathbf{H o}=\boldsymbol{\mu K}=\boldsymbol{\mu S h}$ (There is no significant difference in the opinions of experts in Kosovo and Albania about the importance of internal factors)

Independent sample test for specific environmental factors

Through this test was given the answer to the question: Are there any differences in the opinions of experts from both countries about the importance of specific external factors?

Ho: There are no differences between specific external influencing factors in the E-marketing strategy

Ha: There are differences between specific external influencing factors in the Emarketing strategy

\begin{tabular}{|c|c|c|c|c|c|c|c|c|c|c|}
\hline \multicolumn{11}{|c|}{ Independent Samples Test } \\
\hline & & \multicolumn{2}{|c|}{$\begin{array}{l}\text { Levene's Test } \\
\text { for Equality of } \\
\text { Variances }\end{array}$} & \multicolumn{7}{|c|}{ t-test for Equality of Means } \\
\hline & & \multirow[t]{2}{*}{$\mathrm{F}$} & \multirow[t]{2}{*}{ Sig. } & \multirow[t]{2}{*}{$\mathrm{T}$} & \multirow[t]{2}{*}{ Df } & \multirow[t]{2}{*}{$\begin{array}{l}\text { Sig. (2- } \\
\text { tailed) }\end{array}$} & \multirow[t]{2}{*}{\begin{tabular}{|c|} 
Mean \\
Difference
\end{tabular}} & \multirow[t]{2}{*}{$\begin{array}{l}\text { Std. Error } \\
\text { Difference }\end{array}$} & \multicolumn{2}{|c|}{$\begin{array}{l}95 \% \text { Confidence } \\
\text { Interval of the } \\
\text { Difference }\end{array}$} \\
\hline & & & & & & & & & Lower & Upper \\
\hline \multirow{2}{*}{$\begin{array}{l}\text { Competitor } \\
\text { Identification } \\
\text { and } \\
\text { Competition } \\
\text { Analysis }\end{array}$} & $\begin{array}{l}\text { Equal variances } \\
\text { assumed }\end{array}$ & .073 & .788 & -.913 & 34 & .367 & -.222 & .243 & -.717 & .272 \\
\hline & $\begin{array}{l}\text { Equal variances } \\
\text { not assumed }\end{array}$ & & & -.913 & 33.873 & .367 & -.222 & .243 & -.717 & .272 \\
\hline \multirow{2}{*}{$\begin{array}{l}\text { Relationships } \\
\text { with customers } \\
\text { and suppliers }\end{array}$} & $\begin{array}{l}\text { Equal variances } \\
\text { assumed }\end{array}$ & .377 &. .543 & .190 & 34 &. .851 & .056 & .293 & -.540 & .651 \\
\hline & $\begin{array}{l}\text { Equal variances } \\
\text { not assumed }\end{array}$ & & & .190 & 33.746 &. .851 & .056 & .293 & -.540 & .651 \\
\hline \multirow[t]{2}{*}{ Associates } & $\begin{array}{l}\text { Equal variances } \\
\text { assumed }\end{array}$ & .325 &. .572 & .413 & 34 &. .682 & .111 & .269 & -.435 & .657 \\
\hline & $\begin{array}{l}\text { Equal variances } \\
\text { not assumed }\end{array}$ & & & .413 & 33.914 &. .682 & .111 & .269 & -.435 & .657 \\
\hline
\end{tabular}

Table 4. Independent sample t-test for specific environmental factors. Source: Author.

Based on the results of the t-test for Equality of Means, we were based on Sig. (2tailed) to confirm the hypothesis raised above. The points are $(.367, .851, .682$, ) have a value greater than 0.05 . With a level of $95 \%$ reliability, it can be said that there are no significant differences in the importance of specific external factors in Kosovo and Albania.

$\mathbf{H o}=\boldsymbol{\mu K}=\boldsymbol{\mu S h}$ (There is no significant difference in the opinions of Kosovar and Albanian experts on the importance of specific external factors).

Independent sample test for specific environmental factors

Through this test were given the answers to the question: Are there any differences in the opinions of experts from both countries about the importance of technological factors? 
Ho: There are no differences between the influential technological factors in Emarketing strategy

Ha: There are differences between the influential technological factors in Emarketing strategy

\begin{tabular}{|c|c|c|c|c|c|c|c|c|c|c|}
\hline \multicolumn{11}{|c|}{ Independent Samples Test } \\
\hline & & \multicolumn{9}{|c|}{$\begin{array}{l}\text { Levene's Testt-test for Equality of Means } \\
\text { for Equality of } \\
\text { Variances }\end{array}$} \\
\hline & & \multirow[t]{2}{*}{$\mathrm{F}$} & \multirow[t]{2}{*}{ Sig. } & \multirow[t]{2}{*}{$\mathrm{t}$} & \multirow[t]{2}{*}{$\mathrm{df}$} & \multirow[t]{2}{*}{$\begin{array}{l}\text { Sig. (2- } \\
\text { tailed) }\end{array}$} & \multirow[t]{2}{*}{$\begin{array}{c}\text { Mean } \\
\text { Difference }\end{array}$} & \multirow[t]{2}{*}{$\begin{array}{l}\text { Std. Error } \\
\text { Difference }\end{array}$} & \multicolumn{2}{|c|}{$\begin{array}{l}95 \% \text { Confidence } \\
\text { Interval of the } \\
\text { Difference }\end{array}$} \\
\hline & & & & & & & & & Lower & Upper \\
\hline \multirow[t]{2}{*}{ Innovations } & $\begin{array}{l}\text { Equal } \\
\text { variances } \\
\text { assumed }\end{array}$ & .325 & .572 & .413 & 34 & .682 & .111 & .269 & -.435 & .657 \\
\hline & \begin{tabular}{|l} 
Equal \\
variances not \\
assumed \\
\end{tabular} & & & .413 & 33.914 & .682 & .111 & .269 & -.435 & .657 \\
\hline \multirow[t]{2}{*}{$\begin{array}{l}\text { IT system } \\
\text { standards }\end{array}$} & $\begin{array}{l}\text { Equal } \\
\text { variances } \\
\text { assumed } \\
\end{array}$ & 1.030 & .317 & -1.116 & 34 & .272 & -.278 & .249 & -.783 & .228 \\
\hline & \begin{tabular}{|l} 
Equal \\
variances not \\
assumed
\end{tabular} & & & -1.116 & 33.895 & .272 & -.278 & .249 & -.783 & .228 \\
\hline \multirow{2}{*}{$\begin{array}{l}\text { Human } \\
\text { resources } \\
\text { market (IT } \\
\text { and e- } \\
\text { marketing } \\
\text { specialists } \\
\end{array}$} & $\begin{array}{l}\text { Equal } \\
\text { variances } \\
\text { assumed } \\
\end{array}$ & 2.028 & .164 & .484 & 34 & .631 & .111 & .229 & -.355 & .577 \\
\hline & $\begin{array}{l}\text { Equal } \\
\text { variances not } \\
\text { assumed }\end{array}$ & & & .484 & 32.778 & .631 & .111 & .229 & -.356 & .578 \\
\hline \multirow[t]{2}{*}{$\begin{array}{l}\text { Convenience } \\
\text { of } \\
\text { application }\end{array}$} & $\begin{array}{l}\text { Equal } \\
\text { variances } \\
\text { assumed }\end{array}$ & .728 & .399 & -.968 & 34 & .340 & -.222 & .229 & -.689 & .244 \\
\hline & \begin{tabular}{|l} 
Equal \\
variances not \\
assumed
\end{tabular} & & & -.968 & 32.778 & .340 & -.222 & .229 & -.689 & .245 \\
\hline
\end{tabular}

Table 5. Independent sample t-test for specific environmental factors. Source: Author.

Based on the results of the t-test for Equality of Means, we were based on Sig. (2tailed) to prove the hypothesis raised above. The points are $(.682, .272, .631, .340)$, have a value greater than 0.05 . With a reliability level of $95 \%$, it can be said that there are no significant differences in the importance of technological factors in Kosovo and Albania.

\section{Zero hypothesis is accepted and alternative hypothesis is rejected:}

$\mathbf{H o}=\boldsymbol{\mu} \mathbf{K}=\boldsymbol{\mu S h}$ (There is no significant difference in the opinions of Kosovo and Albania experts on the importance of technological factors).

\section{Independent Samples $t$-test for economic factors}

Through this test were given the answers to the question: Are there any differences in the opinions of experts from both countries about the importance of economic factors? 
Ho: There are no differences between influential economic factors in E-marketing strategy

Ha: There are differences between influential economic factors in E-marketing strategy

\begin{tabular}{|c|c|c|c|c|c|c|c|c|c|c|}
\hline \multicolumn{11}{|c|}{ Independent Samples Test } \\
\hline & & \multicolumn{2}{|c|}{$\begin{array}{l}\text { Levene's Test } \\
\text { for Equality of } \\
\text { Variances }\end{array}$} & \multicolumn{6}{|c|}{ t-test for Equality of Means } & \\
\hline & & \multirow[t]{2}{*}{\begin{tabular}{|l}
$\mathrm{F}$ \\
\end{tabular}} & \multirow[t]{2}{*}{ Sig. } & \multirow[t]{2}{*}{$\mathrm{t}$} & \multirow[t]{2}{*}{$\mathrm{df}$} & \multirow[t]{2}{*}{$\begin{array}{l}\text { Sig. } \\
\text { tailed) }\end{array}$} & \multirow[t]{2}{*}{\begin{tabular}{l|l} 
(2-|Mean \\
Difference
\end{tabular}} & \multicolumn{3}{|c|}{$\begin{array}{l}\text { Std. Error } 95 \% \text { Confidence } \\
\text { Difference Interval of the } \\
\text { Difference }\end{array}$} \\
\hline & & & & & & & & & Lower & Upper \\
\hline \multirow[t]{2}{*}{$\begin{array}{l}\text { The Cost of } \\
\text { adopting e- } \\
\text { marketing }\end{array}$} & \begin{tabular}{|l} 
Equal \\
variances \\
assumed
\end{tabular} & 3.314 & .078 & .406 & 34 & .687 & .111 & .273 & -.445 & .667 \\
\hline & $\begin{array}{l}\text { Equal } \\
\text { variances not } \\
\text { assumed }\end{array}$ & & & .406 & 29.737 & .687 & .111 & .273 & -.448 & .670 \\
\hline \multirow{2}{*}{$\begin{array}{l}\text { The cost of } \\
\text { buying software } \\
\text { package and } \\
\text { hardware }\end{array}$} & $\begin{array}{l}\text { Equal } \\
\text { variances } \\
\text { assumed }\end{array}$ & 4.748 & .036 & .169 & 34 & .867 & .056 & .328 & -.611 & .722 \\
\hline & \begin{tabular}{|l} 
Equal \\
variances not \\
assumed
\end{tabular} & & & .169 & 29.453 & .867 & -.056 & .328 & -.615 & .726 \\
\hline \multirow{2}{*}{$\begin{array}{l}\text { The cost of } \\
\text { maintaining a } \\
\text { web site(trusted } \\
\text { server) }\end{array}$} & \begin{tabular}{|l} 
Equal \\
variances \\
assumed
\end{tabular} & 2.136 & .153 & .853 & 34 & .400 & .222 & .261 & -.307 & .752 \\
\hline & $\begin{array}{l}\text { Equal } \\
\text { variances not } \\
\text { assumed }\end{array}$ & & & .853 & 29.397 & .401 & .222 & .261 & -.310 & .755 \\
\hline \multirow{2}{*}{$\begin{array}{l}\text { Advertising fees } \\
\text { for } \\
\text { representation on } \\
\text { search engines }\end{array}$} & $\begin{array}{l}\text { Equal } \\
\text { variances } \\
\text { assumed }\end{array}$ & 1.761 & .193 & -1.014 & 34 & .318 & -.278 & .274 & -.834 & .279 \\
\hline & $\begin{array}{l}\text { Equal } \\
\text { variances not } \\
\text { assumed }\end{array}$ & & & -1.014 & 32.426 & .318 & -.278 & .274 & -.835 & .280 \\
\hline \multirow[t]{2}{*}{$\begin{array}{l}\text { Cost of } \\
\text { installation or } \\
\text { service }\end{array}$} & \begin{tabular}{|l} 
Equal \\
variances \\
assumed
\end{tabular} & 4.784 & .036 & .496 & 34 & .623 & .167 & .336 & -.516 & .849 \\
\hline & $\begin{array}{l}\text { Equal } \\
\text { variances not } \\
\text { assumed }\end{array}$ & & & .496 & 28.896 & .623 & .167 & .33 & -.520 & .854 \\
\hline \multirow{2}{*}{\begin{tabular}{|l} 
The cost of \\
specialized \\
persons \\
employment
\end{tabular}} & $\begin{array}{l}\text { Equal } \\
\text { variances } \\
\text { assumed }\end{array}$ & 3.134 & .086 & .415 & 34 & .680 & .111 & .267 & -.432 & .655 \\
\hline & $\begin{array}{l}\text { Equal } \\
\text { variances not } \\
\text { assumed }\end{array}$ & & & .415 & 32.095 & .681 & .111 & .267 & -.434 & .656 \\
\hline
\end{tabular}

Table 6. Independent Samples t-test for economic factors. Source: Author.

Based on the results of the t-test for Equality of Means, we were based on Sig. (2tailed) to confirm the hypothesis raised above. The points are $(.687, .867, .400, .381$, $.623, .680)$, and have a value greater than 0.05 . With a $95 \%$ reliability level, it can be 
said that there are no significant differences in the importance of economic factors in Kosovo and Albania.

\section{Zero hypothesis is accepted and alternative hypothesis is rejected:}

$\mathbf{H o}=\boldsymbol{\mu} \mathbf{K}=\boldsymbol{\mu} \mathbf{S h}$ (There is no significant difference in the opinions of Kosovo and Albania experts on the importance of economic factors).

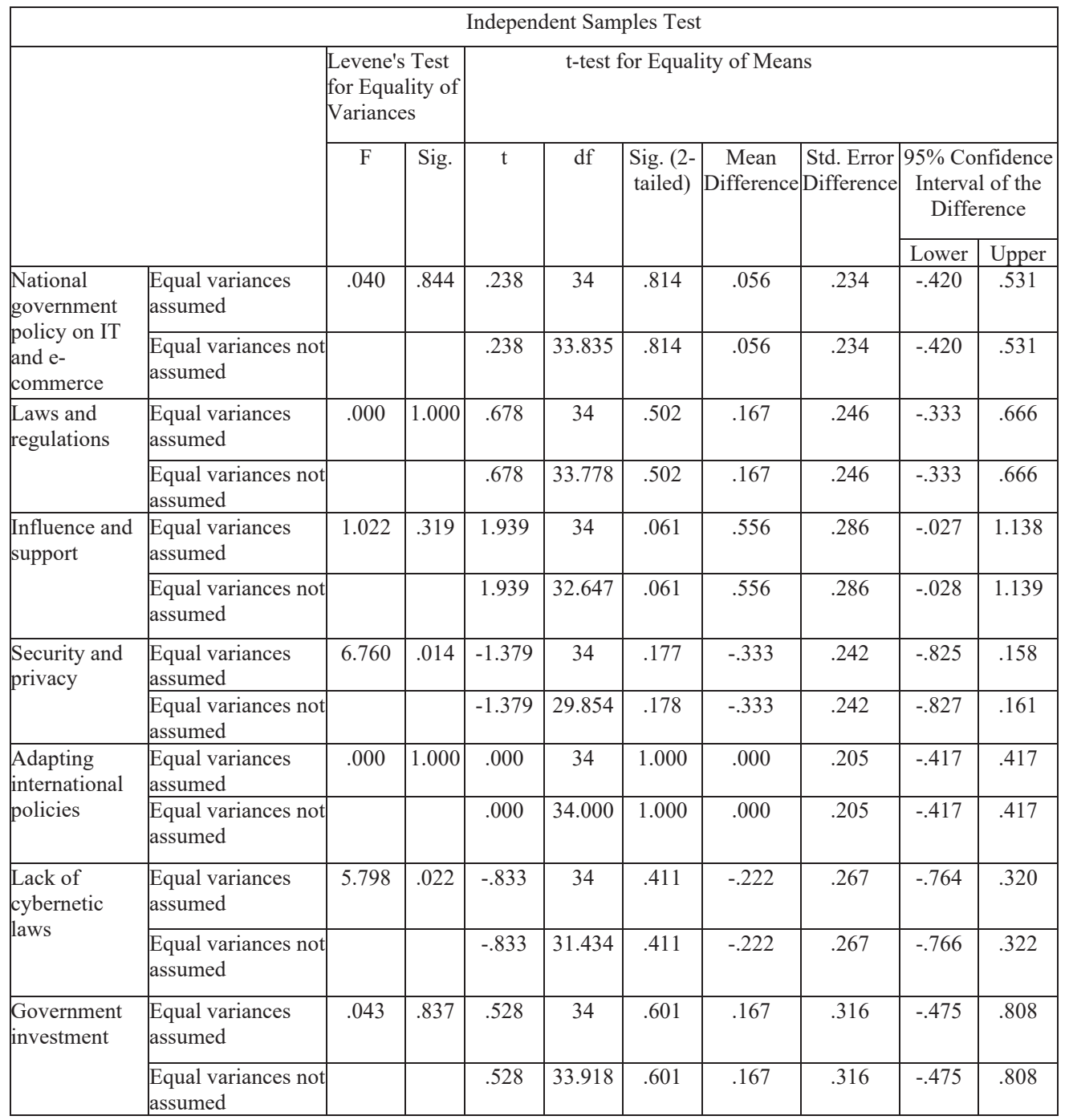

Table 7. Independent Samples t-test for political and legal factors. Source: Author.

Based on the results of the t-test for Equality of Means, we were based on Sig. (2tailed) to prove the hypothesis raised above. The points are $(.814, .502, .061,1.00$, .601 ) and have a value greater than 0.05 , except for the two questions that in Levene's 
Test for Equality of Variance of Significance are .014 and .022, however sig values (2-tailed) are .177 and .411.

With a 95\% reliability level, it can be said that there are no significant differences in the importance of political and legal factors in Kosovo and Albania. Ho $=\boldsymbol{\mu K}=$ $\boldsymbol{\mu S h}$ (There is no significant difference in the opinions of experts in Kosovo and Albania about the importance of political and legal factors).

\section{Independent Samples $t$ Test for cultural and social factors}

Through this test was given the answer to the question: Are there any differences in the opinions of experts of the two countries about the importance of political and legal factors?

Ho: There is no difference between influential political and legal factors in Emarketing strategy

Ha: There are differences between influential political and legal factors in Emarketing strategy

\begin{tabular}{|c|c|c|c|c|c|c|c|c|c|c|}
\hline & & & & ndeper & dent Sar & ples Test & & & & \\
\hline & & $\begin{array}{l}\text { Leven } \\
\text { for Eq } \\
\text { Varian }\end{array}$ & $\begin{array}{l}\text { s Test } \\
\text { ality of } \\
\text { es }\end{array}$ & $\overline{\text { t-test } \mathrm{f}}$ & or Equal & $\mathrm{y}$ of Mea & & & & \\
\hline & & $\mathrm{F}$ & Sig. & $\mathrm{t}$ & $\mathrm{df}$ & $\begin{array}{l}\text { Sig. (2- } \\
\text { tailed }\end{array}$ & \begin{tabular}{|c|} 
Mean \\
Difference
\end{tabular} & \begin{tabular}{|l|} 
Std. Error \\
Difference
\end{tabular} & $\begin{array}{r}95 \% \mathrm{C} \\
\text { Intery } \\
\text { Diff } \\
\end{array}$ & $\begin{array}{l}\text { idence } \\
\text { of the } \\
\text { nce }\end{array}$ \\
\hline & & & & & & & & & Lower & Upper \\
\hline $\begin{array}{l}\text { The general } \\
\text { culture of }\end{array}$ & $\begin{array}{l}\text { Equal variances } \\
\text { assumed }\end{array}$ & .003 & .958 & 699 & 34 & .489 & .167 & .238 & -.318 & .651 \\
\hline organization & $\begin{array}{l}\text { Equal variances } \\
\text { not assumed }\end{array}$ & & & .699 & 33.922 & .489 & .167 & .238 & -.318 & .651 \\
\hline 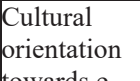 & $\begin{array}{l}\text { Equal variances } \\
\text { assumed }\end{array}$ & .002 & .962 & -.433 & 34 & .667 & -.111 & .256 & -.632 & .410 \\
\hline $\begin{array}{l}\text { marketing } \\
\text { by } \\
\text { ogranization } \\
\text { customers }\end{array}$ & $\begin{array}{l}\text { Equal variances } \\
\text { not assumed }\end{array}$ & & & -.433 & 33.934 & .667 & -.111 & .256 & -.632 & .410 \\
\hline $\begin{array}{l}\text { General } \\
\text { knowledge } \\
\text { of society in }\end{array}$ & $\begin{array}{l}\text { Equal variances } \\
\text { assumed }\end{array}$ & .080 & .778 & .246 & 34 & .807 & .056 & .226 & -.403 & .515 \\
\hline $\begin{array}{l}\text { Information } \\
\text { Technology }\end{array}$ & \begin{tabular}{|l} 
Equal \\
variances not \\
assumed \\
\end{tabular} & & & .246 & 33.733 & .807 & .056 & .226 & -.404 & .515 \\
\hline $\begin{array}{l}\text { Role and } \\
\text { status in }\end{array}$ & $\begin{array}{l}\text { Equal variances } \\
\text { assumed }\end{array}$ & 1.516 & .227 & 1.917 & 34 & .064 & .444 & .232 & -.027 & .916 \\
\hline & $\begin{array}{l}\text { Equal variances } \\
\text { not assumed }\end{array}$ & & & 1.917 & 33.975 & .064 & .444 & .232 & -.027 & .916 \\
\hline $\begin{array}{l}\text { The level of } \\
\text { quality of } \\
\text { university }\end{array}$ & $\begin{array}{l}\text { Equal variances } \\
\text { assumed }\end{array}$ & .284 & .597 & .206 & 34 & .838 & .056 & .270 & -.493 & .604 \\
\hline $\begin{array}{l}\text { programs in } \\
\text { this regard }\end{array}$ & $\begin{array}{l}\text { Equal variances } \\
\text { not assumed }\end{array}$ & & & .206 & 33.798 & .838 & .056 & .270 & -.493 & .604 \\
\hline
\end{tabular}

Table 8. Independent Samples t- test for cultural and social factors. Source: Author. 
Based on the results of the t-test for Equality of Means, we were based on Sig. (2tailed) to prove the hypothesis raised above. The points are $(.489, .667, .807, .064$, $\mathbf{8 3 8}$ ) and have a value greater than 0.05 . With a reliability level of $95 \%$, it can be said that there are no significant differences in the importance of cultural and social factors in Kosovo and Albania. Ho $=\boldsymbol{\mu K}=\boldsymbol{\mu S h}$ (There is no significant difference in the opinions of experts in Kosovo and Albania about the significance of cultural and social factors)

\section{Frideman Test}

It is a non-parameterical test that tests the difference between several related samples[55].

This test confirmed the hypotheses as follows:

1. H0: There is no difference between the eight internal factors

Ha: There is a difference between the eight internal factors

2. H0: There is no difference between the three separate external factors

Ha: There is a difference between the three separate external factors

3. H0: There is no difference between the five technological factors

Ha: There is a difference between the five technological factors

4. H0: There is no difference between the six economic factors

Ha: There is a difference between the six economic factors

5. H0: There is no difference between the seven political and legal factors

Ha: There is a difference between the seven political and legal factors

6. H0: There are no differences between cultural and social influential factors on E-marketing strategy

Ha: There are differences between cultural and social influential factors on Emarketing strategy

\begin{tabular}{|l|c|c|c|c|}
\hline \multicolumn{5}{|c|}{ Test Statistics $^{\mathrm{a}}$} \\
\hline Factors & $\mathbf{N}$ & Ch-Square & Df & Asymp.Sig \\
\hline Internal factors & 36 & 20.715 & 7 & .004 \\
\hline $\begin{array}{l}\text { Specific factors of } \\
\text { environment }\end{array}$ & 36 & .740 & 2 & .691 \\
\hline Technological factors & 36 & 2.647 & 4 & .023 \\
\hline Economic factors & 36 & 12.997 & 5 & .002 \\
\hline $\begin{array}{l}\text { Political and legal } \\
\text { factors }\end{array}$ & 36 & 20.876 & 6 & .602 \\
\hline $\begin{array}{l}\text { Cultural and social } \\
\text { factors }\end{array}$ & 36 & 2.739 & 4 & \\
\hline
\end{tabular}

Table 9. Frideman Test. Source: Author.

Frideman Test Results:

Zero hypothesis rejected, accepted - Ha: There is a difference between the eight internal factors

The HO hypothesis is accepted: There is no difference between the three specific external factors 
The $H_{0}$ hypothesis is accepted: There is no difference between the five technological factors

Zero hypothesis is rejected - Ha accepted: There is a difference between the six economic factors

Zero hypothesis is rejected - Ha accepted: There is a difference between the seven political and legal factors

Hypothesis accepted: Ho: There is no difference between the five cultural and social factors.

Also, this test was done in the second phase to rank which of the internal, special environmental, technological, economic, political and legal factors, and cultural and social factors is more significant according to experts of Kosovo and Albania.

\begin{tabular}{|c|c|c|}
\hline & \multicolumn{2}{|l|}{ Ranks } \\
\hline Factors & & Mean Rank \\
\hline \multirow{8}{*}{ INTERNAL FACTORS } & 1. Firm characteristics & 3.17 \\
\hline & 2. Cooperation between departments & 2.88 \\
\hline & 3. Human resources skills in e-marketing & 2.86 \\
\hline & 4. Appropriateness of use and technical availability & 2.92 \\
\hline & 5. Owner / manager characteristics & 3.18 \\
\hline & 6. Attitudes and knowledge of entrepreneurs & 4.92 \\
\hline & 7. Management support & 5.01 \\
\hline & 8. Operation of marketing and e-marketing activities & 5.03 \\
\hline \multirow[t]{3}{*}{ ENVIRONMENT SPECIAL FACTORS } & $\begin{array}{l}\text { 1. Competitor Identification and Competition } \\
\text { Analysis }\end{array}$ & 2.04 \\
\hline & 2. Relationships with customers and suppliers & 2.04 \\
\hline & 3. Associates/Partners & 1.92 \\
\hline \multirow[t]{5}{*}{ TECHNOLOGICAL FACTORS } & 1. Innovations & 2.97 \\
\hline & 2. TI cost & 2.97 \\
\hline & 3. Sandards of IT systems & 2.86 \\
\hline & $\begin{array}{l}\text { 4. Human resources market and, IT and e-marketing } \\
\text { specialists }\end{array}$ & 2.92 \\
\hline & 5. Covenience of application & 3.28 \\
\hline \multirow{6}{*}{ ECONOMIC FACTORS } & 1. The cost of adapting e-marketing & 3.54 \\
\hline & $\begin{array}{l}\text { 2. The cost of purchasing software and hardware } \\
\text { packages }\end{array}$ & 3.11 \\
\hline & 3. The cost of maintaining a reliable web server & 3.68 \\
\hline & $\begin{array}{l}\text { 4. Advertising fees for representation in search } \\
\text { engines }\end{array}$ & 3.56 \\
\hline & 5. The cost of service installation & 3.08 \\
\hline & 6. The cost of hiring specialists & 4.03 \\
\hline \multirow[t]{7}{*}{ POLITICAL AND LEGAL FACTORS } & $\begin{array}{l}\text { 1. National government policy on IT and e- } \\
\text { commerce }\end{array}$ & 3.60 \\
\hline & 2. Laws and regulations & 3.57 \\
\hline & 3. Influence and support & 3.64 \\
\hline & 4. Security and privacy & 4.88 \\
\hline & 5. Adaptation of international policies & 4.60 \\
\hline & 6. Lack of cybernetic laws & 3.96 \\
\hline & 7. Government investment & 3.76 \\
\hline \multirow[t]{4}{*}{ CULTURAL AND SOCIAL FACTORS } & 1. The general culture of the organization & 3.17 \\
\hline & $\begin{array}{l}\text { 2. Cultural orientation towards E-marketing by } \\
\text { ogranization customers }\end{array}$ & 2.888 \\
\hline & $\begin{array}{l}\text { 3. General knowledge of society on information } \\
\text { technology }\end{array}$ & 2.86 \\
\hline & 4. Role and status in society & 2.92 \\
\hline
\end{tabular}


\begin{tabular}{|l|l|l|}
\hline & $\begin{array}{l}\text { 5. The level of quality of university programs in this } \\
\text { regard }\end{array}$ & $\mathbf{3 . 1 8}$ \\
\hline
\end{tabular}

Table 10. Frideman Tests Ranking. Source: Author.

According to the opinions of Kosovo and Albania experts, it turns out that the operation of marketing and E-marketing activities is one of the most important internal factors that influence the E-marketing strategy. Regarding the significance, two distinct external factors are ranked at the same level, such as competitor identification and competitor analysis and customer and supplier correlations as the most important and influential in the e-marketing strategy. All five technological factors have a rough ranking in terms of importance and influence on the e-marketing strategy, so they were reviewed and analyzed in the third phase of the research to see if there is any change in the ranking. The cost of hiring specialized people is the most important economic and influential factor in the e-marketing strategy. Among the political and legal factors of higher importance, it turns out that security, privacy, and adaptation of international policies by experts in Kosovo and Albania, are of higher significance. According to the experts in Kosovo and Albania, the level of quality of university programs for E-marketing management is considered to be the most important cultural and social factor. The overall culture of the organization influences the E-marketing strategy in the tourism industry as well.

\subsection{The third phase of research}

In the third phase, an online questionnaire from the results of the second phase was used, according to the scale of the report, based on the AHP method. So, the third questionnaire was sent again to the same group of experts from Kosovo and Albania, to reconsider their opinions, but now in a different form, according to the scale of the report from the paired comparisons. This scale is derived from the main vector, Eigen. For the processing of the results the AHP-OS system was used, a system created by Goepel, K.D., (2018), also, from this system, there was the possibility of sending the online questionnaire through the link to the experts. However, being a bit complicated to complete, the questionnaire was created via https://my.survio.com/, however, according to the same form that this system offers. Subsequently, the answers of each expert were transferred to this system by the author of this paper.

Presentation of results according to AHP method

- The goal is: Factors influencing E-marketing strategy

- The criteria are: Internal factors, special environmental factors, technological factors, economic factors, political and legal factors, and cultural and social factors.

- The sub-criteria:

Sub-Internal-Factors (Operation of marketing and e-marketing activities, Management support, Attitudes and knowledge of entrepreneurs);

Sub-Specific Environmental Factors (Competitor Identification and Analysis, Customer and Supplier Relationships);

Technological Sub- Factors (Innovations, IT Cost, IT System Standards); 
Economic Sub-Factors (Cost of Employment of specialists, Cost of Maintaining a Reliable Server Website, Advertising Fees for Representation in Search Engines);

Political and Legal Sub-Factors (Security and Privacy, Adaptation of International Policies, Lack of Cyber Laws);

Cultural and Social Sub-factors (Level of quality of university programs in this regard, General culture of the organization, Role and status in society).

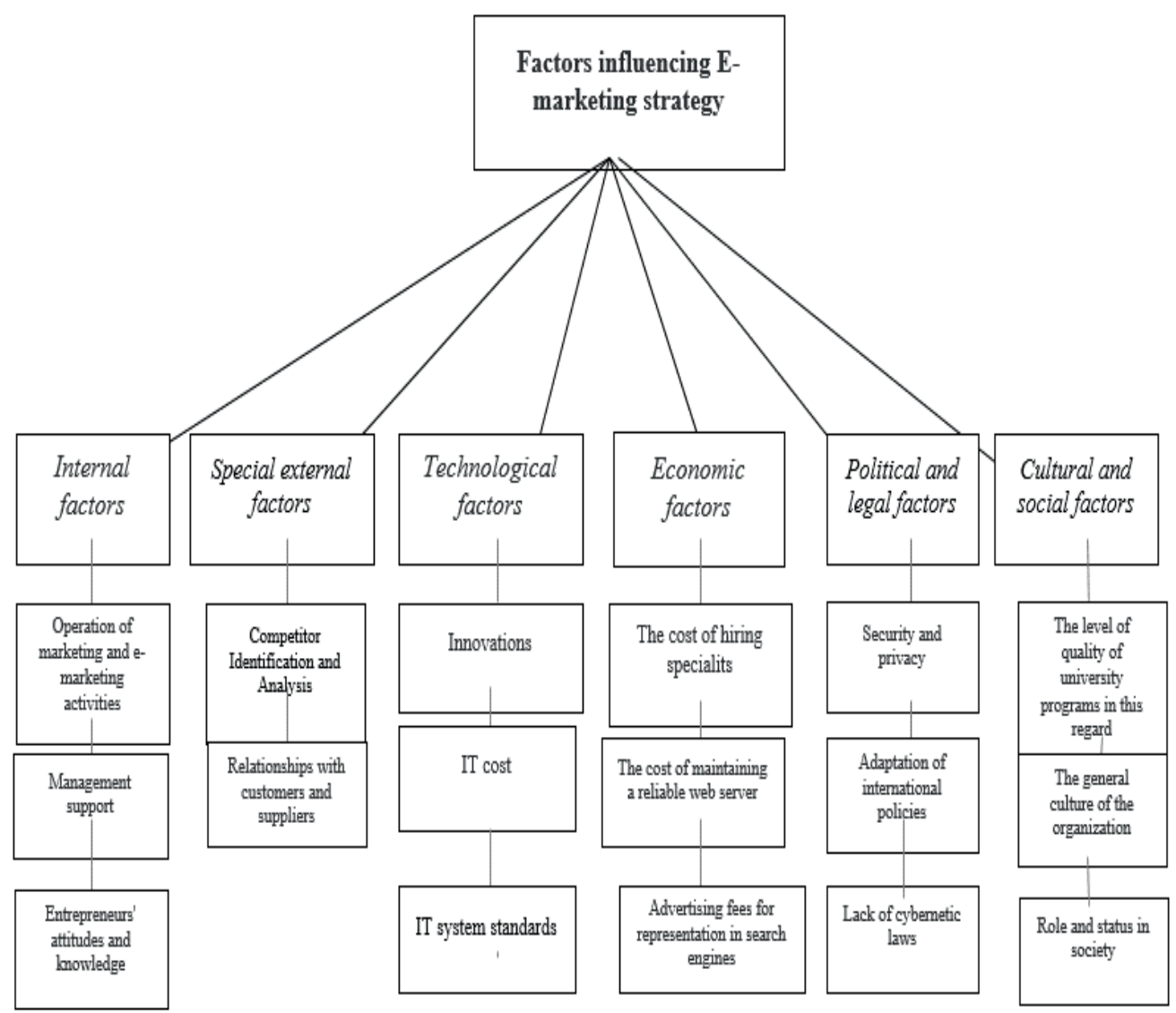

Figure 9. Hierarchical structure of research according to AHP method. Source: Author.

Table 11 summarized the overall results in percentages for all influential Emarketing strategy factors and sub-factors. The overall ratio (CR-consistency ratio) is: $\mathrm{CR}=1.3 \%<10.0$. The consistency ratio is less than $10 \%$, so the matrix is consistent and can be continued with the decision-making process. The consensus within the group is $71.5 \%$, for values below $50 \%$, it is said that there is no consensus within the group of participants and there is a high variety of judgments. However, in our case, 
there is a moderate consensus between the participating groups and there is no high variety of judgments.

\begin{tabular}{|c|c|c|c|}
\hline \multicolumn{4}{|c|}{ Decision Hierarchy } \\
\hline Objectives & Criteria & Sub-criteria & $\begin{array}{l}\text { Glb Prio.( } \\
\text { The weight of } \\
\text { importance) }\end{array}$ \\
\hline \multirow{17}{*}{$\begin{array}{l}\text { Factors } \\
\text { influencing } \\
\text { e-marketing } \\
\text { strategy }\end{array}$} & \multirow[t]{3}{*}{$\begin{array}{l}\text { Internal } \\
\text { factors } \mathbf{0 . 2 6 9}\end{array}$} & $\begin{array}{l}\text { Operation of marketing activities and } \\
\text { e-marketing } \mathbf{0 . 2 5 3}\end{array}$ & $6.8 \%$ \\
\hline & & Management support $\mathbf{0 . 3 6 3}$ & $9.8 \%$ \\
\hline & & $\begin{array}{l}\text { Relationships with customers and } \\
\text { suppliers } \mathbf{0 . 3 8 4}\end{array}$ & $10.3 \%$ \\
\hline & \multirow{2}{*}{$\begin{array}{l}\text { Special } \\
\text { external } \\
\text { factors } \mathbf{0 . 1 5 8}\end{array}$} & $\begin{array}{l}\text { Competitor Identification and Analysis } \\
\mathbf{0 . 4 8 8}\end{array}$ & $7.7 \%$ \\
\hline & & $\begin{array}{l}\text { Relationships with customers and } \\
\text { suppliers } \mathbf{0 . 5 1 2}\end{array}$ & $8.1 \%$ \\
\hline & \multirow{3}{*}{$\begin{array}{l}\text { Technological } \\
\text { factors } \mathbf{0 . 1 9 2}\end{array}$} & Innovations 0.387 & $7.4 \%$ \\
\hline & & IT cost 0.406 & $7.8 \%$ \\
\hline & & IT system standards $\mathbf{0 . 2 0 7}$ & $4.0 \%$ \\
\hline & \multirow{3}{*}{$\begin{array}{l}\text { Economic } \\
\text { factors } \mathbf{0 . 1 5 0}\end{array}$} & The cost of hiring specialists $\mathbf{0 . 3 1 2}$ & $4.7 \%$ \\
\hline & & $\begin{array}{l}\text { The cost of maintaining a reliable web } \\
\text { server } \mathbf{0 . 3 2 5}\end{array}$ & $4.9 \%$ \\
\hline & & $\begin{array}{l}\text { Advertising fees for representation in } \\
\text { search engines } \mathbf{0 . 3 6 2}\end{array}$ & $5.4 \%$ \\
\hline & \multirow{3}{*}{$\begin{array}{l}\text { Political and } \\
\text { legal factors } \\
\mathbf{0 . 1 2 5}\end{array}$} & Security and privacy $\mathbf{0 . 3 6 5}$ & $4.6 \%$ \\
\hline & & $\begin{array}{l}\text { Adaptation of international policies } \\
\mathbf{0 . 3 7 6}\end{array}$ & $4.7 \%$ \\
\hline & & Lack of cyber laws $\mathbf{0 . 2 5 9}$ & $3.2 \%$ \\
\hline & \multirow{3}{*}{$\begin{array}{l}\text { Cultural and } \\
\text { social factors } \\
\mathbf{0 . 1 0 6}\end{array}$} & $\begin{array}{l}\text { The level of quality of university } \\
\text { programs in this regard } \mathbf{0 . 3 8 3}\end{array}$ & $4.1 \%$ \\
\hline & & $\begin{array}{l}\text { The general culture of the organization } \\
\mathbf{0 . 3 7 0}\end{array}$ & $3.9 \%$ \\
\hline & & Role and status in society $\mathbf{0 . 2 4 7}$ & $2.6 \%$ \\
\hline & & & 1.0 \\
\hline
\end{tabular}

Table 11. Consolidated Priorities Hierarchy. Source: Author.

In the second column of the table above, the results are presented in percentages for the criteria (internal factors, special environmental factors, technological factors, economic factors, political and legal factors, and cultural and social factors). Also, in the third column, are the percentage results for the sub-criteria (internal sub-factors, special environmental sub-factors, technological sub-factors, economic sub-factors, political and legal sub-factors, and cultural and social sub-factors). Whereas, in the fourth column are presented the consolidated results according to the weight of importance of the factors that influence the e-marketing strategy, in the tourism industry in Kosovo and Albania. As shown, the attitudes and knowledge of entrepreneurs have a higher weight of significance $10.30 \%$, management support $9.80 \%$, customer and supplier correlation $8.10 \%$, IT cost 7.80 , competitor 
identification and analysis $7.70 \%$, and innovation $7.40 \%$. The other set of factors has a lower weight in correlation to the factors mentioned above.

\section{Conclusion}

Based on the literature review it can be concluded that the scientific theories that need to be analyzed to determine the adaptation of IT and the factors influencing the Emarketing strategy are: Reasoning Action Theory (TRA), Planned Behavior Theory (TPB), Innovation Dissemination Theory (IDT), Technological, Organizational and Environmental Framework (TTOM) Theory, Technology Acceptance Model (TAM), Common Technology Acceptance and Use Theory (UTAUT) and Contingency Theory. The TRA and TPB should be studied in cases where consumer behavior is analyzed because it provides clarification on how consumers act online and offline. IDT makes a contribution when it is intended to know the reactions of individuals to an innovation, ie to understand how this idea is perceived. This theory consists of a process by which an innovation is communicated through certain channels between members of a society over time. It is considered one of the theories through which the factors that influence individuals to adopt an innovative technology can be identified. Also, through the TOE structure, the three most important aspects that influence an enterprise to implement technology are identified. Decision making for technological innovation is done by analyzing the environmental context (industry characteristics and organizational structure, technological infrastructure support, government rules), organizational context (formal and informal structure, communication process, and size) and the technological context (technology availability and its features). Also, to clarify the reasons why technology is used and accepted by users, as well as by consumers, the TAM and UTAUT theory is used. We have considered the theory of contingency as the basic theory of this paper because according to this theory, the definition of strategy depends on environmental variables, organizational factors, and strategic response. This theory includes three types of variables, such as unforeseen variables, performance variables, and response variables, which are considered quite important in formulating the strategy of an enterprise. In the theoretical aspect, the factors that influence e-marketing strategy are: clear e-marketing policies, cost, resources, cultural orientation towards marketing, infrastructure, competition, owner characteristics, level of education, age, general technological knowledge, enterprise size, management style, organizational structure, application of technology, IT characteristics, marketing department, customer satisfaction, etc.

In the study of E-marketing strategy and E-strategy process in the tourism industry, it was used the sample of 36 experts, who are experts of the tourism industry in Kosovo and Albania, individuals who have university qualifications and work in the positions of marketing managers and sales at hotel enterprises, travel agencies, tour operators and airlines. Based on the results of the third phase, it can be concluded that the internal factors are the most important factors of the six criteria. Among the internal factors (attitudes and knowledge of entrepreneurs), special environmental factors (relationships with customers and suppliers), technological factors (innovations and cost of IT), economic factors (advertising fees for representation in 
search engines), political and legal factors (adaptation of international policies), cultural and social factors (the general culture of the organization), are the most influential factors in the E-marketing strategy according to the AHP method analysis. Whereas of all the factors and sub-factors, according to the importance, attitudes, and knowledge of entrepreneurs, management support, customer relations, and suppliers, IT cost, competitor identification, competitor analysis, and innovation have the highest influence.

\section{Recommendations}

Based on the contingency theory, and also in the TEO framework, the model in Figure 10 has been proposed. It is recommended to be analyzed by tourism industry sectors, as it can help in defining proper E-marketing strategy. The factors presented in this model are determined based on the findings of this research.

From the proposed model the following recommendations have been derived:

- Every entrepreneur should be knowledgeable of the benefits offered by Emarketing and have a positive attitude since the role of e-marketing on the tourism industry is pivotal. Businesses that have shifted from traditional marketing to online forms have had better success compared to businesses that have not followed this trend.

- It is recommended that senior management should support marketing activities by allocating sufficient budget for these activities and not to consider unnecessary expenses. It is not given enough importance to marketing in Kosovo and Albania, particularly, E-marketing.

- In cases of the lack of E-marketing specialized staff, it is necessary to hire or collaborate with specialized/professional E-marketing agencies.

- To be on track with the trends of technological development concerning developed countries, because only in this way they keep up with the competition. The cost of technology should not be a hindrance to businesses, because it results in high profits.

- Train staff in the area of E-marketing because human resources are a strong pillar for an institution.

- The importance of consumers to the marketing concept lies at the forefront, so more advanced services should be offered, especially in the tourism industry where the tourist travels to the country he or she wants to see and there is no possibility of going to the destination in advance. Based on this, everyone makes a decision based on recent online information.

- Establish continuous contacts with customers. It is recommended for all businesses to create online ways where customers can express their satisfaction and dissatisfaction because only in this way they can make continuous improvement in all the services they offer. Work more on security and privacy issues, because in Kosovo, as well as in Albania, many businesses and clients fear that their data may be misused and used for other purposes. 
- Review the policies and laws of developed countries regarding consumer rights to let them know that there is a well-controlled system in these countries in order to make use of the goods and services offered online.

- For public and private universities to work towards quality in the field of Emarketing, offering more professional programs in this field, as it is a segment that needs to be emphasized. Specialists should be in the right positions, as it turns out that non-specialized staff is employed in the e-marketing position. This was proved by the fact that it was difficult to find experts in this field.

- Researchers should focus more on the role of technology and, especially Emarketing, in the field of tourism.

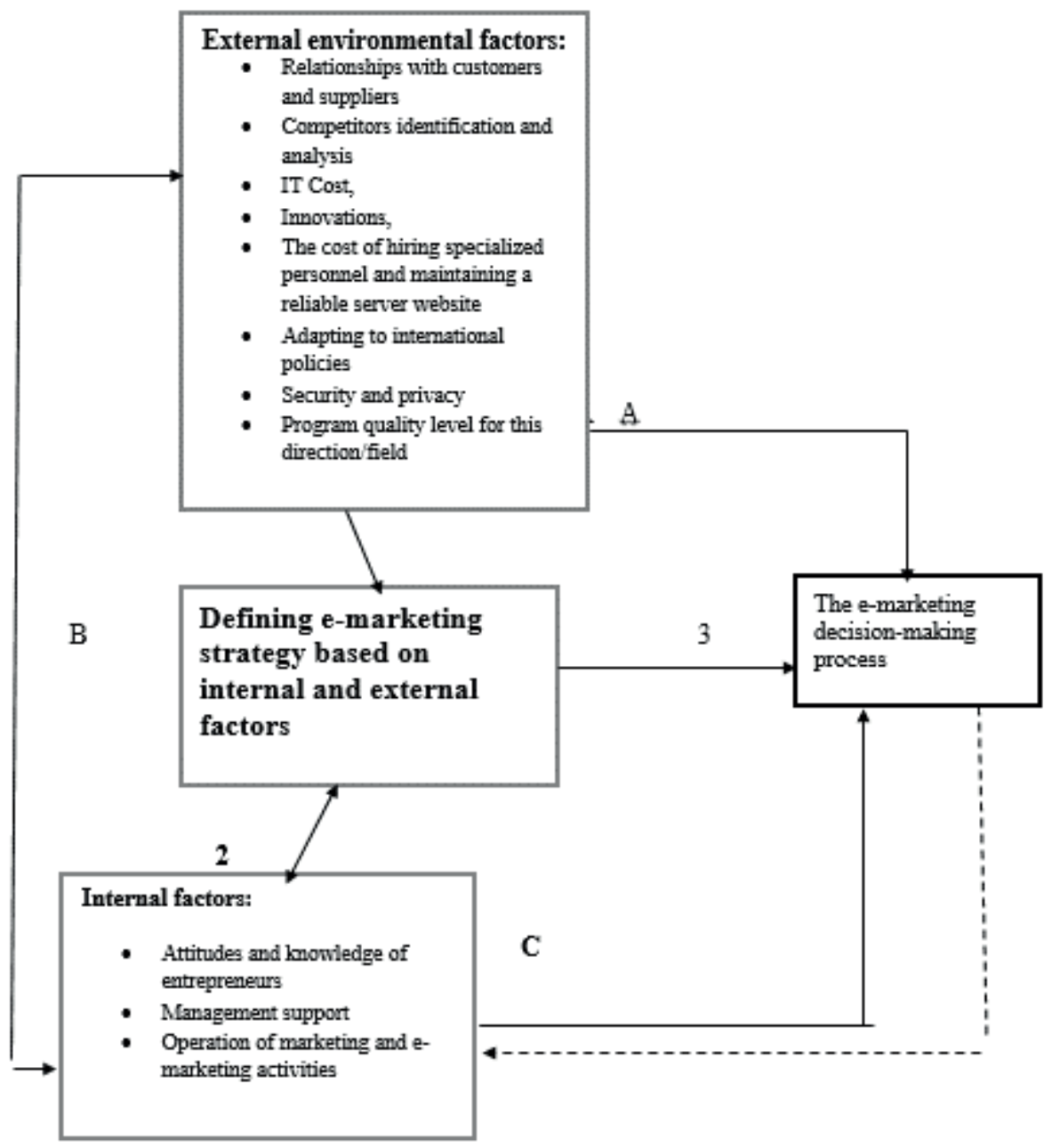

Figure 10. The model recommended by the author on contingent factors based on contingency theory. Source: Author, based on [38]. 


\section{References}

[1] P. J. Benckendorrf, Z. Xiang, and P. Sheldon, Tourism Information Tecnnology, Third. Boston, Massachusetts, CABI, 2019.

[2] I. Ilić and A. Nikolić, "Implications of modern technology development for the tourism sector of the Republic of Serbia," Ekonomika, vol. 64, no. 1, pp. 37-52, 2018, doi: 10.5937/ekonomika1801037i.

[3] N. Shabani, A. Munir, and A. Hassan, "E-Marketing via Augmented Reality: A Case Study in the Tourism and Hospitality Industry," IEEE Potentials, vol. 38, no. 1, pp. 43-47, 2019, doi: 10.1109/MPOT.2018.2850598.

[4] K. D. Goepel, "Implementing the Analytic Hierarchy Process as a Standard Method for Multi-Criteria Decision Making in Corporate Enterprises - a New AHP Excel Template with Multiple Inputs," pp. 1-10, 2013, doi: 10.13033/isahp.y2013.047.

[5] T. L. Saaty and L. G. Vargas, Models, Methods, Concepts Sc Applications of the Analytic Hierarchy Process. 2000.

[6] M. I. Dahnil, K. M. Marzuki, J. Langgat, and N. F. Fabeil, "Factors Influencing SMEs Adoption of Social Media Marketing," Procedia - Soc. Behav. Sci., vol. 148, pp. 119-126, 2014, doi: 10.1016/j.sbspro.2014.07.025.

[7] H. El-Gohary, "Factors affecting E-Marketing adoption and implementation in tourism firms: An empirical investigation of Egyptian small tourism organisations," Tour. Manag., vol. 33, no. 5, pp. 1256-1269, 2012, doi: 10.1016/j.tourman.2011.10.013.

[8] T. Iqbal and E. El-Gohary, "An attempt to understand E-Marketing: An information technology prospective department of business administration," Int. J. Bus. Soc. Sci., vol. 5, no. 4, pp. 234-256, 2014.

[9] B. Khalil Moghaddam and A. Khatoon-Abadi, "Factors affecting ICT adoption among rural users: A case study of ICT Center in Iran," Telecomm. Policy, vol. 37, no. 11, pp. 1083-1094, 2013, doi: 10.1016/j.telpol.2013.02.005.

[10] R. Rahayua and John Daya, "Determinant Factors of E-commerce Adoption by SMEs in Developing Country: Evidence from Indonesia," Procedia - Soc. Behav. Sci., vol. 195, pp. 142-150, 2015.

[11] N. Delafrooz and A. Khatibi, "Developing an Instrument for Measurement of Attitude Toward Online Shopping," Eur. J. Soc. Sci., vol. 7, no. 3, pp. 166-177, 2009, doi: 10.1007/s00418-007-0354-y.

[12] P. A. L. C. Pavlou, "WHAT DRIVES ELECTRONIC COMMERCE ACROSS CULTURES? A CROSS-CULTURAL EMPIRICAL 
INVESTIGATION OF THE THEORY OF PLANNED BEHAVIOR,' J. Electron. Commer. Res., vol. 3, no. 4, pp. 1-14, 2002, doi: 10.1016/B9781-78242-103-0.00001-1.

[13] E. Yoh, M. L. Damhorst, S. Sapp, and R. Laczniak, "Consumer Adoption of the Internet: The Case of Apparel Shopping," Psychol. Mark., vol. 20, no. 12, pp. 1095-1118, 2003, doi: 10.1002/mar.10110.

[14] I. Ajzen, “The Theory of Planned Behavior," Organ. Behav. Hum. Decis. Process., vol. 50, no. 2, pp. 179-211, 1991, doi:

10.15288/jsad.2011.72.322.

[15] K. Mathieson, "Comparing The Technology Acceptance Model with The Theory of Planned Behaviour," Inf. Syst. Res., vol. 2, 3, no. 3, pp. 173-191, 1991.

[16] J. F. George, "The theory of planned behavior and Internet purchasing," Internet Res., vol. 14, no. 3, pp. 198-212, 2004, doi:

$10.1108 / 10662240410542634$.

[17] E. M. Rogers and M. Everett, DIFFUSION OF INNOVATIONS, Third. Communication of Innovations: A Cross-Cultural Approach., 1991.

[18] J. Baker, "The Technology-Organization-Environment Framework," Inf. Syst. theory, Springer, pp. 231-245, 2012, doi: 10.1007/978-1-4419-61082.

[19] T. Oliveira et al., "Literature Review of Information Technology Adoption Models at Firm Level," Rev. Adm., vol. 45, no. 1, pp. 110-121, 2010, doi: 10.1017/CBO9781107415324.004.

[20] Y. Alshamaila, S. Papagiannidis, and F. Li, "Cloud computing adoption by SMEs in the north east of England: A multi-perspective framework," J. Enterp. Inf. Manag., vol. 26, no. 3, pp. 250-275, 2013, doi: $10.1108 / 17410391311325225$.

[21] L. Oshlyansky, P. Cairns, and H. Thimbleby, "Validating the Unified Theory of Acceptance and Use of Technology (UTAUT) tool crossculturally," Proc. 21st Br. HCI Gr. Annu. Conf. People Comput. HCI... but not as we know it, vol. 2, pp. 83-86, 2007, doi: 10.1515/zntw.1907.8.1.1.

[22] R. Eid and M. Trueman, "Factors affecting the success of business-tobusiness international Internet marketing (B-to-B IIM): An empirical study of UK companies," Ind. Manag. Data Syst., vol. 104, no. 1-2, pp. 16-30, 2004, doi: 10.1108/02635570410514061.

[23] A. Omar, T. Ramayah, L. B. Lin, O. Mohamad, and M. Marimuthu, "Determining Factors for the Usage of Web-Based Marketing Applications by Small and Medium Enterprises (SMEs) in Malaysia," J. Mark. Dev.

Compet., vol. 5, no. 2, pp. 70-86, 2011, doi: 10.1111/j.14683083.2005.01297.x. 
[24] K. Nusair, M. Erdem, F. Okumus, and A. Bilgihan, "Users' Attitudes Toward Online Social Networks in Travel," in Social Media in Travel, TouriSM and HoSpiTaliTy:Theory, Practice and Cases, M. Sigala, E. Christou, and U. Gretzel, Eds. 2012, pp. 207-221.

[25] H. El-Gohary, "E-Marketing - A Literature Review From A Small Businesses Perspective," Int. J. Bus. Soc. Sci., vol. 1, no. 1, p. n/a, 2010, [Online]. Available:

http://dq4wu5nl3d.search.serialssolutions.com/?ctx_ver=Z39.882004\&ctx_enc=info:ofi/enc:UTF-

8\&rfr_id=info:sid/ProQ:abiglobal\&rft_val_fmt=info:ofi/fmt:kev:mtx:journ al\&rft.genre $=$ unknown\&rft.jtitle $=$ International + Journal + of + Business + and + Social+Science\&rft.a.

[26] H. Celik, "Customer online shopping anxiety within the Unified Theory of Acceptance and Use Technology (UTAUT) framework," Asia Pacific J. Mark. Logist., vol. 28, no. 2, 2016, doi: 10.1108/APJML-05-2015-0077.

[27] E. Abu-Shanab and S. Haider, "Major factors influencing the adoption of m-government in Jordan," Electron. Gov., vol. 11, no. 4, pp. 223-240, 2015, doi: 10.1504/EG.2015.071394.

[28] K. I. Al-Qeisi, "Analyzing the Use of UTAUT Model in Explaining an Online Behaviour: Internet Banking Adoption A,” 2009.

[29] E. Tarcan and E. S. Varol, "Role of the demographic factors in the process of hotel information systems adoption," Turiz. međunarodni Znan. časopis, vol. 58, no. 2, pp. 127-144, 2010.

[30] I. S. Pantelidis, "Technology acceptance of hotel web sites," in Pantelidis, Ioannis S Technology acceptance of hotel websites 2006, 2006.

[31] A. Giovanis, C. Assimakopoulos, and C. Sarmaniotis, "Adoption of mobile self-service retail banking technologies: The role of technology, social, channel and personal factors," Int. J. Retail Distrib. Manag., 2018, doi: 10.1108/IJRDM-05-2018-0089.

[32] N. Dlodlo and M. Dhurup, "Drivers of E-Marketing Adoption among Small and Medium Enterprises (SMEs) and Variations with Age of Business Owners," Mediterr. J. Soc. Sci., vol. 4, no. 14, pp. 53-66, 2013, doi: 10.5901/mjss.2013.v4n14p53.

[33] V. Venkatesh, J. Y. L. Thong, and X. Xu, "CONSUMER ACCEPTANCE AND USE OF INFORMATION TECHNOLOGY: EXTENDING THE UNIFIED THEORY OF ACCEPTANCE AND USE OF TECHNOLOGY," MIS Q., vol. 36, no. 1, pp. 157-178, 2012, doi: $10.1042 /$ bst0120672.

[34] K. S. Tan, S. C. Chong, and B. Lin, "Intention to use internet marketing: A comparative study between Malaysians and South Koreans," Kybernetes, 
vol. 42, no. 6, pp. 888-905, 2013, doi: 10.1108/K-12-2012-0122.

[35] V. Venkatesh, M. G. Morris, G. B. Davis, and F. D. Davis, "User Acceptance of Information Technology: Toward a Unified View," MIS Q., vol. 27, no. 3, pp. 425-478, 2003, doi: 10.1016/j.inoche.2016.03.015.

[36] Y. S. Wang and Y. W. Shih, "Why do people use information kiosks? A validation of the Unified Theory of Acceptance and Use of Technology," Government Information Quarterly, vol. 26, no. 1. pp. 158-165, 2009, doi: 10.1016/j.giq.2008.07.001.

[37] H. San Martín and Á. Herrero, “Influence of the user's psychological factors on the online purchase intention in rural tourism: Integrating innovativeness to the UTAUT framework," Tour. Manag., vol. 33, no. 2, pp. 341-350, 2012, doi: 10.1016/j.tourman.2011.04.003.

[38] J. Reinking, "Contingency Theory in Information Systems Research," in Information Systems Theory, Springer, Y. K. Dwivedi, M. R. Wade, and S. L. Schneberger, Eds. 2012, pp. 247-263.

[39] A. Ginsberg and N. Venkatraman, "Contingency Perspectives of Organizational Strategy: A Critical Review of the Empirical Research," Acad. Manag. Rev., vol. 10, no. 3, pp. 421-434, 1985, doi: 10.5465/amr.1985.4278950.

[40] C. J. Tarter and W. K. Hoy, “of Decision Making,” no. 1998, 2005.

[41] L. F. Lages and S. D. Jap, “A CONTINGENCY APPROACH TO MARKETING MIX ADAPTATION AND PERFORMANCE IN INTERNATIONAL MARKETING RELATIONSHIPS,” pp. 1-46, 2002.

[42] W. Schertler and D. Buhalis, Information and communication technologies in tourism 1999 : proceedings of the international conference in Innsbruck, Austria, 1999. 1999.

[43] M. Hasan, M. Jabiullah, I. Ahamed, and N. Chakma, "Prospects of ETourism Ecosystem in Bangladesh: Services and Infrastructure," DIU J. Sci. Technol., vol. 10, no. 1, pp. 10-20, 2016.

[44] S. S. Mousavi, "Effective Elements on E-Marketing strategy in Tourism Industry (Case study Germany and Iran Airlines, Tour Operator and Chain Hotels)," University Trier Faculty VI, 2012.

[45] N. Levenburg, S. Magal, and P. Kosalge, “An Exploratory Investigation of Organizational Factors and e-Business Motivations Among SMFOEs in the US," Electron. Mark., vol. 16, no. 1, pp. 70-84, 2006, doi: 10.1080/10196780500491402.

[46] F. Rahimnia and J. F. Hassanzadeh, "The impact of website content dimension and e-trust on e-marketing effectiveness: The case of Iranian commercial saffron corporations," Inf. Manag., vol. 50, no. 5, pp. 240-247, 
2013, doi: 10.1016/j.im.2013.04.003.

[47] K. J. Trainor, A. Rapp, L. S. Beitelspacher, and N. Schillewaert, "Integrating information technology and marketing: An examination of the drivers and outcomes of e-Marketing capability," Ind. Mark. Manag., vol. 40, no. 1, pp. 162-174, 2011, doi: 10.1016/j.indmarman.2010.05.001.

[48] B. Achieng, "How SMEs are using Online Marketing to Improve their Competitiveness in Kenya: A Case Study of Tembea East Africa Safaris," United States Int. Univ. - Africa, no. Fall, 2016, [Online]. Available: http://erepo.usiu.ac.ke/bitstream/handle/11732/3093/BILHA ACHIENG 2016.pdf? sequence $=1 \&$ is Allowed $=\mathrm{y}$.

[49] D. Buhalis and H. Main, "Information technology in peripheral small and medium hospitality enterprises: Strategic analysis and critical factors," Int. J. Contemp. Hosp. Manag., vol. 10, no. 5, pp. 198-202, 1998, doi: 10.1108/09596119810227811.

[50] R. Law, D. Buhalis, and C. Cobanoglu, "Progress on information and communication technologies in hospitality and tourism," Int. J. Contemp. Hosp. Manag., vol. 26, no. 5, pp. 727-750, 2014, doi: 10.1108/IJCHM-082013-0367.

[51] E. Ramsey and P. McCole, "E-business in professional SMEs: The case of New Zealand," J. Small Bus. Enterp. Dev., vol. 12, no. 4, pp. 528-544, 2005, doi: 10.1108/14626000510628207.

[52] S. Hays, S. J. Page, and D. Buhalis, "Social media as a destination marketing tool: Its use by national tourism organisations," Curr. Issues Tour., vol. 16, no. 3, pp. 211-239, 2013, doi: 10.1080/13683500.2012.662215.

[53] E. Constantinides, "Social Media / Web 2.0 as Marketing Parameter: An Introduction," Media, no. March, pp. 0-25, 2017.

[54] M. Sigala, "Developing and Benchmarking Internet Marketing Strategies in the Hotel Sector in Greece," J. Hosp. Tour. Res., vol. 27, no. 4, pp. 375401, 2003, doi: 10.1177/10963480030274001.

[55] S. B. Green and N. Salkind, Using SPSS for Windows and Macintosh ANALYZING AND UNDERSTANDING DATA, Seventh., vol. 66. Pearson Education, Inc., 1 Lake St., Upper Saddle River, NJ 07458., 2014. 